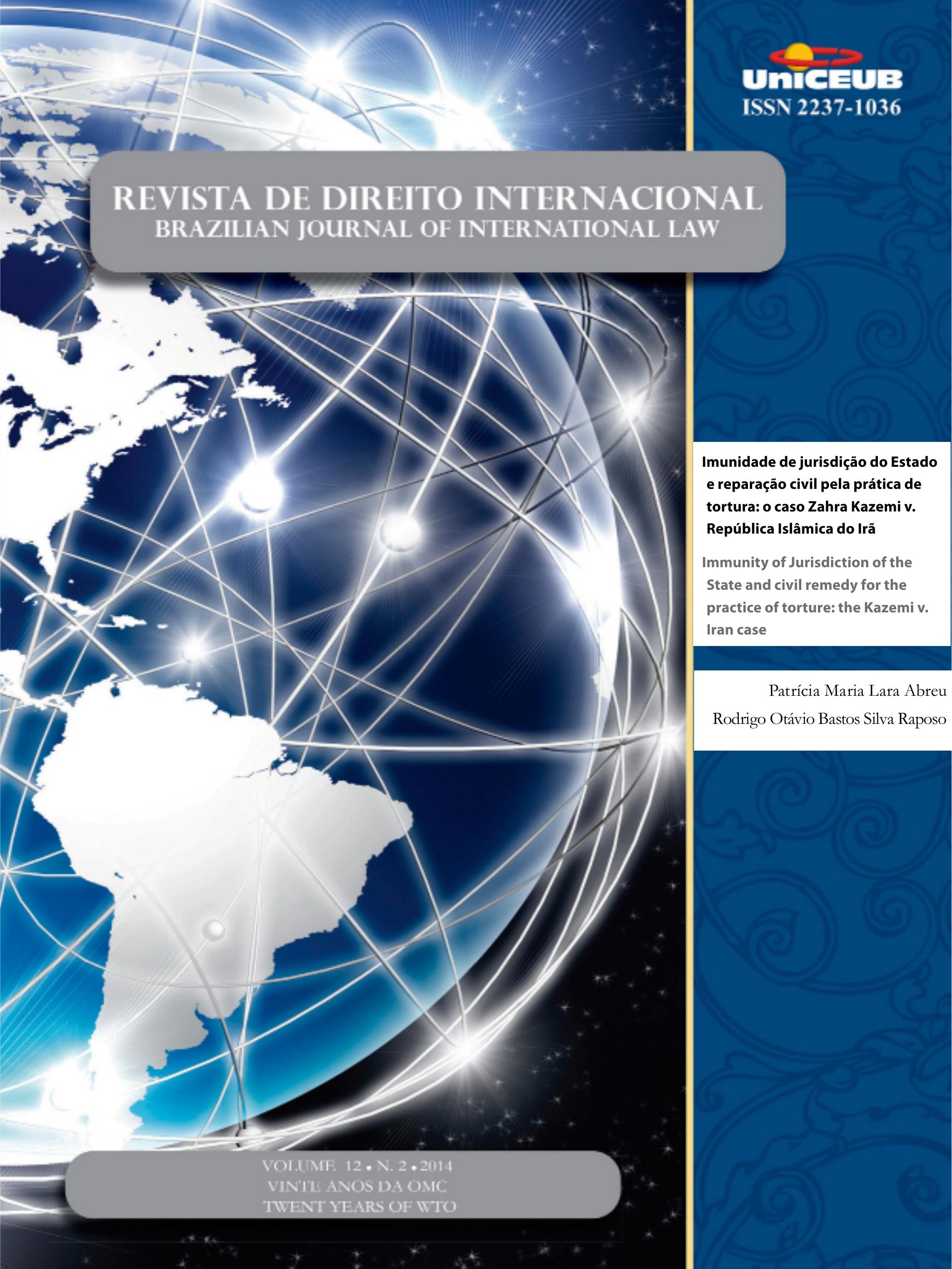


I. Crônicas

1. Crônicas da atualidade do Direito Internacional ......................................................16

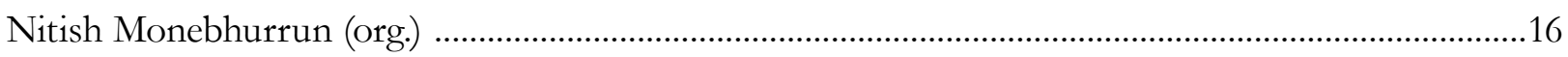

2.Decisões da Corte Internacional de Justiça e do Tribunal Internacional Sobre o Direito do Mar

Nitish Monebhurrun

José Eduardo Siqueira

3. Crônicas do direito internacional dos inVestimentos

Nitish Monebhurrun

\section{Os Vinte Anos dA OMC}

EXPORT CONTROLS AS INDUSTRIAL POLICY ON NATURAL RESOURCES: REGULATORY LIMITATIONS ON CHINA - RAW MATERIALS AND CHINA - RARE EARTHS CASES.

Gustavo Ferreira Ribeiro

O problema da espionagem econômica internacional: Seria a Organização Mundial do CoMÉRCIO O FORO ADEQUADO PARA SUA APRECIAÇÃO?

Humberto A.Vasconcelos Lima

Naiana Magrini Rodrigues Cunha

International Standards for Intellectual Property Rights Protection: a reflection on CLIMATE-FRIENDLY TECHNOLOGY TRANSFER.

Guihong Zhang

Jiani Jiang

Can Wang

Os vinte anos da OMC, suas conquistas e desafios: uma análise do Brasil e o Sistema de SoLUÇõES DE CONTROvÉRsias

Etiene M. Bosco Breviglieri

Luciano Meneguetti Pereira

A relação entre os tratados multilaterais ambientais e os acordos da OMC: é possível CONCILIAR O CONFLITO?

Fabio Costa Morosini,

Luisa Zuardi Niencheski 
Um desafio na Organização Mundial do Comércio: viabilidade de um aCordo plurilateral

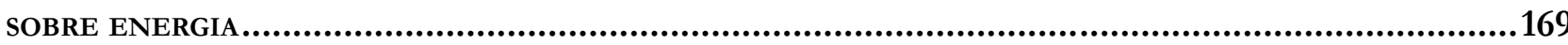

Matheus Linck Bassani

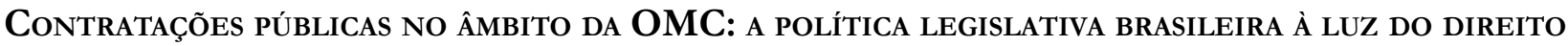
AO DESENVOLVIMENTO

André Jansen do Nascimento

Governança global e a Organização Mundial do Comércio: desafios impostos pelo novo MANDATO DE DESENVOLVIMENTO

Letícia de Souza Daibert

Ana Luísa Soares Peres

Vinte Anos de Crise para a África? Poder, Assimetrias e a Abordagem liberal da OMC.....239 Igor Abdalla Medina de Souza

Os MECANISMOS DE INDUÇÃo AO CUMPRIMENTO NO ÂMBITO DA OMC 258

Fernando Lopes Ferraz Elias

A promoção de accountability na Organização Mundial do Comércio: uma análise hori-

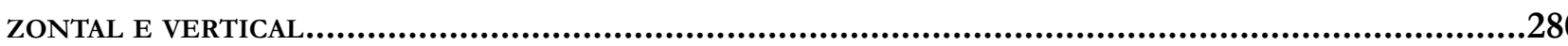

Celso Henrique Cadete de Figueiredo

LA OMC y EL PROCESO DE GLOBALIZACION DE LA REGULACIÓN ALIMENTARIA

Maria Eugenia Marichal

O ACORDO GATS E SUA APLICAÇÃo AOS SERVIÇOS DO COMÉRCIO ELETRÔNICO

Gleisse Ribeiro Alves

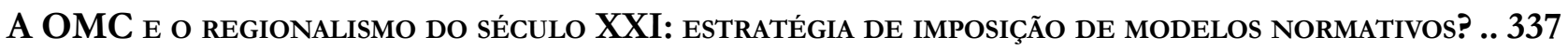

Camilla Capucio

A ORganização MUNDIAL do COMÉRCio E A CHINA: DIREITO DE PROPRIEDADE E PROPRIEDADE INTELECTUAL NO PAÍS.

Dos CONTENCiosos NA OMC COM ENFOQUe EM RESTRições Às EXPORTAÇõEs DA CHINA 363 Marco Antônio Alcântara Nascimento 
Alice Rocha da Silva

\section{Outros Temas}

Derechos Humanos En la REALIDAd aCtual: LA GLOBALIZACión Y El MUlticulturalismo

David Falcão

IMUNIDAdE DE JURISDIÇÃo do EsTAdo E REPARAÇÃo CIVIL PELA PRÁtiCA DE TORTURA: O CASO ZaHRA

KAZEMI v. REPÚBLICA ISLÂMICA DO IRÃ.

Patrícia Maria Lara Abreu

Rodrigo Otávio Bastos Silva Raposo

INTERREGIONAL ORgANIZATIONS (IROS) IN EUROPE: NEW SUBJECTS OF CONTEMPORARY INTERNATIONAL LAW?

Davorin Lapas

A CONEXÃo ENTRE OS Direitos humanos E A CORRUPÇão

Gabriela Alves Mendes Vieira

Marcelo Dias Varella

GRUPO DE SOCIEDADES: INSTRUMENTO JURÍDICO DE ORGANIZAÇÃO DA EMPRESA PLURISSOCIETÁRIA.....495

Daniel Amin Ferraz 


\title{
Imunidade de jurisdição do Estado e reparação civil pela prática de tortura: o caso Zahra Kazemi v. República Islâmica do Irã*
}

\author{
Immunity of Jurisdiction of the State and civil \\ remedy for the practice of torture: the Kazemi v. \\ Iran case
}

\author{
Patrícia Maria Lara Abreu** \\ Rodrigo Otávio Bastos Silva Raposo***
}

\section{Resumo}

A Suprema Corte do Canadá, ao julgar o pedido de reparação civil decorrente da prisão, estupro e morte de Zahra Kazemi, sob custódia da República Islâmica do Irã, em 2003, confirmou o posicionamento de instâncias anteriores da justiça canadense, que decidiram pela manutenção da imunidade de jurisdição do Estado iraniano mesmo diante das alegações de violação de jus cogens e de incidência de uma das exceções à imunidade de jurisdição previstas no Canada State Immunity Act. O julgamento ilustra a tendência atual de manutenção da prerrogativa de imunidade de jurisdição dos Estados em matéria civil, mesmo diante da prática de tortura.

Palavras-chave: Caso Kazemi. Tortura. Imunidade de Jurisdição.

\section{Abstract}

The Supreme Court of Canada have already done its judgment on the plea for civil damages arising out of the prison, rape and death of Zahra Kazemi under custody of the Islamic Republic of Iran in 2003, confirming the results given by earlier instances of the Canadian justice, which have decided to maintain the immunity from jurisdiction of the Iranian State despite alleged jus cogens violations and possible occurrence of an exception to sovereign immunity stated in Canada State Immunity Act. The trial illustrates the current trend of maintaining the prerogative of jurisdictional immunity of States in civil matters, even in face of the practice of torture.

Keywords: Kazemi Case. Torture. State Immunity.

* Recebido em 14.07.2014
Aceito em 02.12 .2014

** Acadêmica do Curso de Direito da Universidade Estadual do Maranhão (UEMA).

*** Professor dos Cursos de Direito da Universidade Estadual do Maranhão (UEMA) e da UNDB (MA). rodrigobastosraposo@hotmail.com.

\section{Introdução}

Normas de direitos humanos com caráter de jus cogens podem justificar o afastamento da imunidade de jurisdição de um Estado soberano? Essa questão, que foi razão de discussão no julgamento do caso Alemanha versus Itália na Corte Internacional de Justiça em 2012 ${ }^{1}$, chegou mais uma vez a uma Corte Suprema, dessa vez a do Canadá, onde aguarda julgamento. Trata-se de um pedido de

1 CORTE INTERNACIONAL DE JUSTIÇA. Jurisdictional Immunities of the State (Germany v. Italy: Greece intervening): Application Instituting Proceedings. 2008. Available at: <http://www.icj-cij.org/ docket/files/143/16883.pdf>. Last access on: 29 maio 2014. 
indenização pela prática de tortura e consequente morte de uma jornalista canadense no Irã. A ação foi apresentada pelo espólio e pelo filho da vítima e envolve a interpretação do Canada State Immunity Act e a possibilidade de alargar as hipóteses de exceção à imunidade de jurisdição em vista da prática de tortura ${ }^{2}$.

Com relação à interpretação da legislação canadense, a questão diz respeito a uma hipótese de competência prevista na legislação desse país pela qual um Estado não fará jus a imunidade se houver causado dano no território do Canadá. No caso, embora a vítima de tortura estivesse no Irã, seu filho, que é autor da ação indenizatória junto com o espólio, estava em território canadense e lá sofreu com a prisão, com os maus tratos e com a morte de sua mãe. Resta às cortes canadenses responderem se esse sofrimento foi causado pelo Irã em território canadense e se esse sofrimento subsumese na hipótese de competência acima mencionada.

Quanto à ampliação das hipóteses de exceção à imunidade de jurisdição em decorrência da prática de tortura, esta remete à discussão sobre o possível conflito entre as normas de jus cogens e as normas relativas à imunidade de jurisdição. O jus cogens é composto pelas normas peremptórias de direito internacional, cuja derrogação só é possível por outra norma da mesma natureza. Essa caracterização do jus cogens, constante do artigo 53 da Convenção de Viena sobre Direito dos Tratados ${ }^{3}$, traduz dois elementos fundamentais dessa categoria normativa: sua obrigatoriedade e sua inderrogabilidade. Ambos os elementos nascem dos mesmos componentes objetivo e subjetivo que formam o costume internacional, mas não se prendem a eles, pois frente a essas normas não há possibilidade de objeção e, uma vez em vigor, a sua derrogação exige uma nova manifestação de vontade da comunidade internacional, dotada da mesma dignidade.

A noção de normas peremptórias é caudatária da ideia de comunidade internacional, que por sua

2 CANADÁ. Supreme Court of Canada. Estate of the Late Zabra (Ziba) Kazemi, et al. v. Islamic Republic of Iran, et al.: 2014 SCC 62. Available at: <http://scc-csc.lexum.com/scc-csc/scc-csc/en/ item/14384/index.do>. Last access on: 26 out. 2014.

3 Convenção de Viena sobre o Direito dos Tratados de 1969, art. 53: É nulo um tratado que, no momento de sua conclusão, conflite com uma norma imperativa de Direito Internacional geral. Para os fins da presente Convenção, uma norma imperativa de Direito Internacional geral é uma norma aceita e reconhecida pela comunidade internacional dos Estados como um todo, como norma da qual nenhuma derrogação é permitida e que só pode ser modificada por norma ulterior de Direito Internacional geral da mesma natureza. vez é uma concepção da sociedade internacional em torno da qual se debate desde o primeiro quartel do século XX. Depois de quase um século de evolução da doutrina jus-internacionalista, sob o impacto de enormes mudanças culturais, políticas e econômicas, e sob o peso de tragédias humanitárias sucessivas, cuja recordação, infelizmente, não chega a esvanecer entre os episódios, a existência de tal categoria de normas já não é contestada. Os debates travam-se agora em torno da definição dos contornos dessa categoria normativa e das obrigações que dela decorrem para os Estados.

Quanto à identificação das normas de jus cogens, há visões mais expansivas e visões mais restritivas. As primeiras elaboram a categoria de modo amplo, buscando dar fundamento legal a diversos pleitos nos campos dos direitos humanos, do direito humanitário, do direito ao desenvolvimento, ao trabalho, à saúde e ao meio ambiente, de forma a superar as reticências dos Estados à obrigatoriedade desses direitos. As últimas tratam a categoria com circunspecção, procurando limitar seu alcance às prescrições jurídicas de conteúdo mais essencial e indiscutível e alertando para o valor jurídico fundamental do conceito de soberania.

Embora relevante, a questão da identificação das normas de jus cogens foge ao objeto deste estudo, que irá focar a questão das obrigações decorrentes dessa categoria normativa e, principalmente, como irá o judiciário canadense resolver o alegado conflito entre as normas internacionais que vedam a prática da tortura e as normas internacionais que preveem a imunidade de jurisdição dos Estados. O julgamento do caso Alemanha $v$. Itália é bem conhecido e sabese que a maioria dos juízes da Corte Internacional de Justiça posicionou-se de modo a distinguir entre o campo de atuação das normas de jus cogens, as quais teriam como foco condutas materiais, e o campo de atuação das normas relativas à imunidade de jurisdição, que afetariam questões procedimentais. É bem sabido também que a própria Corte destacou que o seu papel não é criar normas, mas sim, aplicar as vigentes. No entanto, em seu julgamento, a Corte também ponderou que o direito internacional é um sistema normativo em evolução e que o julgamento não liquida a questão.

De fato, se levar-se em conta que as normas de jus cogens possuem uma natureza fortemente costumeira, chegar-se-á facilmente à conclusão de que a prática dos Estados, isto é, a forma como os Estados as interpretam e aplicam, irá alterar o teor delas. Por 
isso, quando a Itália julgou processos de reparação civil contra a Alemanha pelos crimes cometidos na II Guerra Mundial, a Corte Internacional de Justiça entendeu que tais atos violavam as obrigações da Itália perante a Alemanha. No entanto, se tribunais nacionais passarem a considerar o impacto das normas peremptórias de direito internacional para afastar a imunidade de jurisdição, o entendimento do alcance e da aplicação dessas normas irá se alterar. Por isso, em se tratando da relação entre imunidade de jurisdição e jus cogens, cada julgamento nacional conta para a evolução do direito internacional na matéria.

A análise do Caso Kazemi se mostra, desta forma, interessante na medida em que as argumentações desenvolvidas ao longo do seu desenrolar são frutos não de uma situação isolada, mas da construção de uma jurisprudência no Direito Canadense sobre o assunto, já enfrentado anteriormente por aquele país em casos como Bouzariv. Islamic Republic of Iran ${ }^{4}$, R.v.Hape, [2007 $]^{5}$, entre outros, em consonância com aquilo que debatido e decidido em outros países, em cortes regionais e até mesmo na própria Corte Internacional de Justiça ${ }^{6}$, o que permite que a partir dele se possa traçar o panorama geral acerca da possibilidade ou não de caracterização da prática de tortura como condição suficiente para constituir exceção à imunidade de jurisdição do estado estrangeiro.

Tendo isso em vista, o presente trabalho cuidará da análise dos institutos da imunidade de jurisdição dos estados soberanos e da prática da tortura a partir das decisões prolatadas nas Cortes canadenses quando do julgamento do Caso Kazemi. Neste ínterim, analisarse-ão, além dos conceitos e fundamentos destes institutos, conceitos e fundamentos de institutos correlatos como o das normas de jus cogens, soberania e direitos humanos, bem como os argumentos das partes em litígio e a jurisprudência construída a partir destes.

4 CANADÁ. Court of Appeal for Ontario. Bouzari v. Islamic Republic of Iran (2004), 71 O.R. (3d) 675. Available at: <http:// www.canlii.org/en/on/onca/doc/2004/2004canlii871/2004canl ii871.html>. Last access on: 28 maio 2014.

5 CANADÁ. Supreme Court of Canda. R.v.Hape, [2007] 2S.C.R. 292, 2007 SCC 26. Available at: <http://scc-csclexum.com/scc-csc/scc-csc/ en/item/2364/index.do?r= AAAAAQAjQm91emFyaSB2L iBJc2xhbWljI FJlcHVibGljIG9mIElyYW4AAAAAAQ>. Last access on: 28 maio 2014.

6 CORTE INTERNACIONAL DE JUSTIÇA. Jurisdictional Immunities of the State (Germany v. Italy: Greece intervening): Application Instituting Proceedings (2008). Available at: <http:// www.icj-cij.org/docket/files/ 143/16883.pdf>. Last access on: 29 maio 2014
Apresentar-se-á primeiramente um resumo dos fatos, com apresentação das partes e seus argumentos, das questões procedimentais da jurisdição canadense pertinentes, procedendo-se à individualização das condutas e a uma breve síntese sobre a questão da tortura no plano internacional contemporâneo frente às noções de jus cogens e imunidade de jurisdição do Estado. O capítulo seguinte cuidará do desenvolvimento do Caso Kazemi em primeiro grau, com análise dos fundamentos da acusação e da defesa, em especial no que toca à previsão legal sobre o tratamento dispensado à imunidade de jurisdição no Canadá e à pretensa possibilidade de normas de jus cogens configurarem exceção àquela. Em seguida, abordar-se-á, a partir dos fundamentos da Corte de Apelação, a questão da constitucionalidade das normas que asseguram a imunidade de jurisdição frente à violação de direitos constante da Carta Maior canadense e seus instrumentos, e da definição e extensão das hipóteses de competência, enquanto exceções à garantia da imunidade de jurisdição. Por fim, e tendo por base todos os argumentos sustentados nas instâncias anteriores, analisar-se à questão enfrentada pela Suprema Corte Canadense da adequação do SIA ao ordenamento jurídico-constitucional canadense, notadamente quanto a questões de segurança pessoal e violação a princípios fundamentais de justiça.

\section{0 caso Kazemi e a disputa entre $j u s$ cogens e imunidade de jurisdição}

Antes de se analisar propriamente o posicionamento do Estado canadense em relação à manutenção da imunidade de jurisdição do estado estrangeiro e sua extensão aos servidores que agindo nesta qualidade praticarem atos de tortura, a partir dos fundamentos jurídicos utilizados nas decisões prolatadas ao longo do Caso Kazemi, importa que sejam delineadas as bases fáticas e teóricas tidas por plano de fundo de referida argumentação.

Neste condão, a exposição cronológica dos acontecimentos que deram azo ao caso, bem como aqueles efetivados perante a Justiça canadense, e a delimitação dos institutos teóricos fundamentais para a resolução da temática, notadamente o da própria imunidade de jurisdição e das normas de jus cogens, como a proibição da prática de tortura, se mostram imprescindíveis. 
Portanto, a função deste item é situar o leitor em relação aos fatos e ao andamento do caso na justiça canadense, o que é feito no item 2.1, bem como introduzir a questão teórica de fundo, que é a disputa entre as categorias jus cogens e imunidade de jurisdição, o que é feito no item 2.2. A partir desses elementos, espera-se que o leitor compreenda a importância do caso e o contexto maior no qual sua análise está inserida.

\subsection{O assassinato de Zahra Khazemi e a busca por reparação civil na justiça canadense}

Em 2003, Zahra Kazemi, fotógrafa iraniana e canadense, foi presa no Irã, torturada, abusada sexualmente por autoridades do Estado iraniano, vindo a falecer em consequência dos ferimentos causados por estes atos. O espólio de Zahra Kazemi e seu filho iniciaram, na província de Quebec, uma ação de responsabilidade civil contra o Estado do Irã, seu Chefe de Estado e outras autoridades. Em sua ação, os autores pediram indenização pela dor e sofrimento que os atos do Irã e de seus agentes causaram e pediram ainda, conforme permite o direito canadense, que a condenação fosse substancialmente ampliada de modo a tornar-se punitiva e exemplar. Ao contestar, o Irã e os demais demandados solicitaram o arquivamento da ação, sob o fundamento de que esta era vetada pelo princípio da imunidade de jurisdição do Estado, como definido no artigo 3 do Canada State Immunity Act (doravante SIA). O dispositivo estabelece, como um preceito geral, a proibição do conhecimento de ações contra Estados estrangeiros perante as cortes daquele país, salvo consentimento expresso daqueles neste sentido. ${ }^{7}$ Em sua réplica, os requerentes afirmaram que repelir sua pretensão com base no SI $A$ seria uma afronta à Constituição, pois eles seriam privados do direito de buscar, perante o judiciário canadense, reparação contra os danos sofridos. ${ }^{8}$

Assim, alegaram os requerentes estar fundado seu direito à persecução civil frente o Estado iraniano e suas autoridades pela tortura, abuso e morte da Sra. Kazemi, bem como pelo dano psicológico sofrido por

7 A análise deste dispositivo será feita mais detidamente no item 3.1 deste trabalho.

8 CANADÁ. Supreme Court of Canada. Estate of the Late Zahra (Ziba) Kazemi, et al. v. Islamic Republic of Iran, et al: Summary. Available at: <http://www.scc-csc.gc.ca/case-dossier/info/sumsom-eng.aspx?cas $=35034>$. Last access on: 29 maio 2014 . seu filho em decorrência daqueles acontecimentos, suscitando, ainda, a possível incongruência do SIA com dispositivos da Constituição canadense e de sua Carta de Direitos e Liberdades Individuais e com o entendimento do Direito Internacional de considerar jus cogens a proibição do uso da tortura, de forma que a aplicação da imunidade de jurisdição em casos como o presente consistiria afronta ao ordenamento jurídico internacional.

Buscando referida reparação, ingressaram com a ação na Quebec Superior Court of Justice, corte de primeira instância da província do Quebec, dotada de competência territorial e material para julgar o caso.? Esta, em decisão da lavra do juiz Robert Mongeon, rejeitou a ação no tocante ao espólio da Sra. Kazemi, por entender que, uma vez que as agressões e o evento morte se deram em Teerã, e não em território canadense, como exige o art. 6(a) do $S I A,{ }^{10}$ o evento em que se funda sua pretensão não se amolda à exceção contida naquele artigo.

No tocante ao Sr. Hashemi, entretanto, entendeu o juiz Robert Mongeon estarem preenchidos os requisitos para se afastar a imunidade de jurisdição do Irã, uma vez que as ações praticadas contra a Sra. Kazemi, no Irã, repercutiram na integridade pessoal de seu filho no Canadá, de forma que consentido o prosseguimento da ação relativamente aos pedidos levados a feito com base no direito do Sr. Hashemi.

Os requeridos e os requerentes apelaram à Quebec Court of Appeal, que é competente para julgar os recursos contra as decisões da Quebec Superior Court. ${ }^{11}$

9 Art. 75 The domicile of a person, for the exercise of his civil rights, is at the place of his principal establishment. Art. 83 The parties to a juridical act may, in writing, elect domicile with a view to the execution of the act or the exercise of the rights arising from it. Election of domicile is not presumed. CANADA. Quebec Civil Code. Disponível em: <http://www2. publicationsduquebec.gouv.qc.ca/dynamicSearch/telecharge. php?type=2\&file=/CCQ_1991/CCQ1991_A.htm>. Acesso em: 12 jun. 2014.

Art. 23 The jurisdictions of the Court of Appeal, the Superior Court and the Court of Québec extend throughout Québec; the jurisdiction of a municipal court is limited to a designated territory. Art.31 The Superior Court is the court of original general jurisdiction; it hears in first instance every suit not assigned exclusively to another court by a specific provision of law. CANADA. Quebec Code of Civil Procedure. Available at em: <http://www2. publicationsduquebec.gouv.qc.ca/dynamicSearch/telecharge. php?type $=2 \&$ file $=/$ C_25/C25_A.HTM $>$. Last access on: 12 jun. 2014.

10 A análise deste dispositivo se dará de forma mais detida no item 3.1 deste trabalho.

11 Art. 25 The Court of Appeal is the general appeal tribunal for Québec; it hears appeals from any judgment from which an appeal lies, failing an express 
No julgamento do recurso, o voto do excelentíssimo Yves-Marie Morissette, ${ }^{12}$ seguido unanimemente pelos demais julgadores, foi no sentido de manter decisão de primeiro grau no que toca ao espólio da Sra. Kazemi e modificá-la quanto à pretensão do Sr. Hashemi, que foi rejeitada. Ou seja, a decisão do recurso em segundo grau foi favorável ao Irã e à tese da imunidade de jurisdição do Estado. A pretensão do Sr. Hashemi foi rejeitada com base no juízo de que as evidências por ele apresentadas foram insuficientes para a caracterização de dano pessoal na forma do SIA, tendo feito prova apenas de mero dano moral.

Recorreu então o Sr. Hashemi à última corte final de apelação, a saber, a Suprema Corte, ${ }^{13}$ pugnando pela incompatibilidade do SIA, notadamente seu artigo 3(1), com previsões constitucionais e quase constitucionais, como o artigo 2(e) da Bill of Rights e o artigo 7 da Charter. Ouvidos os interventores e $o$ Attorney General of Canada, a Corte Suprema se posicionou, majoritariamente ${ }^{14} \mathrm{e}$ reafirmando o posicionamento esposado pela Court of Appeal no que toca à completude do SIA, ao caráter político e taxativo das exceções nele previstas, à consequente competência exclusiva do Parlamento para sua alteração, à caracterização dos atos de tortura como atos oficiais, à não configuração da exceção do artigo 6(a) pelo dano psicológico sofrido pelo Sr. Hashemi, dentre outros, no sentido de não configurar a prática da tortura, hipótese geradora de jurisdição cível universal; ausente previsão específica no SIA,

provision to the contrary. Art. 26 Unless otherwise provided, an appeal lies (1) from any final judgment of the Superior Court or the Court of Québec, except in a case where the value of the object of the dispute in appeal is less than \$50,000. CANADA. Quebec Code of Civil Procedure. Available at: $<$ http://www2.publicationsduquebec.gouv.qc.ca/dynamicSearch/ telecharge.php?type $=2 \&$ file $=/$ C_25/C25_A.HTM $>$. Last access on: 12 jun. 2014.

12 A análise das alegações das partes e os fundamentos da decisão da Corte dar-se-á com maior profundidade no item 4 e seus subitens, ao qual se remete o leitor.

13 Art. 101 The Parliament of Canada may, notwithstanding anything in this Act from Time to Time provide for the Constitution, Maintenance, and Organization of a General Court of Appeal for Canada, and for the Establishment of any additional Courts for the better Administration of the Laws of Canada. CANADA. Constitution Act, 1867: An Act for the Union of Canada, Nova Scotia, and New Brunswick, and the Government thereof; and for Purposes connected therewith. Available at: <http://laws-lois.justice.gc.ca/eng/Const/page-5. html\#docCont>. Last access on: 12 jun. 2014.

14 A juíza Abella se posicionou no sentido de considerar que a peremptoriedade da proibição da prática de tortura teria criado uma jurisdição cível universal, a exemplo do que já existe no âmbito penal, de forma que competente o Judiciário canadense para a análise do mérito, como se demonstrará no tópico 4. esta não poderá ser considerada exceção à Imunidade de Jurisdição do Estado estrangeiro para fins de persecução da reparação cível no Canadá, de forma que incompetente o Judiciário canadense para conhecer da ação, confirmando a tendência jurisprudencial internacional sobre a matéria ${ }^{15}$.

\subsection{A disputa entre as categorias jus cogens e imunidade de jurisdição no caso Kazemi}

Casos que envolvem a prática de tortura são sempre complexos e de difícil solução para o Direito Internacional, notavelmente no campo da responsabilização de seus atores, ante o reconhecimento, por um lado, da natureza cogente das normas de proibição da prática de tortura, e de outro da completa ausência de dispositivos que obriguem, ou ao menos, prevejam a possibilidade de reparação civil aos ofendidos. O caso Kazemi não foge à regra.

Ao cuidar do assassinato da Sra. Zahra (Ziba) Kazemi, enquanto sob a custódia do Governo Iraniano, após ter sido presa arbitrariamente e sem direito ao devido processo legal, o judiciário canadense enfrentou necessariamente conceitos como o de tortura, jus cogens, direitos humanos, soberania e imunidade de jurisdição, e suas relações, seja sob o prisma do direito internacional, seja sob o prisma de seu próprio direito interno, em especial quando da análise da aplicação e interpretação do SIA.

Mas o que se entende por tortura? Onde estariam os fundamentos para sua proibição e até que ponto a prática desta poderá ser considerada um ilícito internacional com vistas à plena responsabilização de seus autores?

A tortura é conceituada no art. 1.1 da Convenção das Nações Unidas contra a Tortura e Outros Tratamentos ou Penas Cruéis, Desumanos ou Degradantes (Resolução 39/46 da Assembleia Geral das Nações Unidas), de 10 de dezembro de 1984 como

qualquer ato pelo qual dores ou sofrimentos agudos, físicos ou mentais, são infligidos intencionalmente a uma pessoa a fim de obter, dela ou de uma terceira pessoa, informações ou confissões; de castigá-la por ato cometido; de intimidar ou coagir esta pessoa ou

15 CANADÁ. Supreme Court of Canada. Estate of the Late Zabra (Ziba) Kazemi, et al. v. Islamic Republic of Iran, et al.: 2014 SCC 62. Available at: $\quad<$ http://scc-csc.lexum.com/scc-csc/scc-csc/en/item/14384/ index.do >. Last access on: 26 out. 2014. 
outras pessoas; ou por qualquer motivo baseado em discriminação de qualquer natureza; quando tais dores ou sofrimento são infligidos por um funcionário público ou outra pessoa no exercício de funções públicas, ou por sua instigação, ou com o seu consentimento ou aquiescência. Não se considerará como tortura as dores ou sofrimentos consequência unicamente de sanções legítimas, ou que sejam inerentes a tais sanções ou delas decorram. ${ }^{16}$

Este documento é uma das principais fontes formais da obrigatoriedade da vedação à prática de tortura, a qual não pode ser derrogada por situações excepcionais (art. $2^{\circ}$ da Convenção) e cujo caráter jus cogens está fundado nas condições de existência da comunidade internacional, a qual impõe a todos os Estados a observância de um estado de direito internacional no qual aos Estados é juridicamente reconhecida sua soberania, ao mesmo tempo em que pautado o seu exercício no respeito às regras com as quais os Estados se comprometeram ao longo da história ${ }^{17}$.

A inderrogabilidade e a imperatividade das normas de jus cogens podem ainda ser deduzidas da possibilidade de responsabilização penal dos agentes que praticarem ou autorizarem a prática de tortura, a exemplo do ocorrido nos julgamentos do Tribunal de Nuremberg (Tribunal Militar Internacional) acerca dos crimes de guerra praticados pela Alemanha Nazista durante a segunda guerra mundial, e com a posterior criação em 1998, por meio do Estatuto de Roma, do Tribunal Penal Internacional. No entanto, deve-se destacar que, no direito internacional, o tratamento penal da prática de tortura evoluiu de modo diferente de seu tratamento na esfera civil. Quando observado o aspecto criminal, a prática de tortura tem sido alvo de diversa e crescente produção normativa repressiva e punitiva, o que não ocorreu, até o momento, quanto aos seus reflexos civis. Desta forma, a imunidade dos agentes que praticaram ou autorizaram a prática de tortura

16 BRASIL. Decreto n. 40, de 15 de fevereiro de 1991. Promulga a Convenção Contra a Tortura e Outros Tratamentos ou Penas Crueis, Desumanos ou Degradantes. Disponível em: <http:// www.planalto.gov.br/ccivil_03/decreto/1990-1994/D0040.htm>. Acesso em: 22 maio 2014.

17 “[...] (o) Estado está subordinado ao direito natural, assim como às regras criadas pelo costume internacional. Sua soberania não é soberania absoluta; trata-se de uma competência dada aos Estados pelo direito nacional e o direito positivo dos povos". VERDROSS, Alfred. O Fundamento do Direito Internacional. Revista de Direito Internacional, v. 10, n. 2, p. 1-33, 2013. p. 29. Disponível em: < http:// www. publicacoesacademicas.uniceub.br/index.php/rdi/article/ view/2685>. Acesso em: 23 abr. 2014. não é mais um obstáculo a sua persecução criminal, seja no plano internacional, seja no plano interno dos Estados, desde que haja uma razoável conexão entre o crime praticado e o foro de julgamento. Por outro lado, no que diz respeito às reparações civis, o que há é o funcionamento dos sistemas de monitoramento e julgamento internacionais previamente autorizados pelos Estados, ao passo que, no plano das jurisdições internas, o que há é a previsão, na legislação interna, de exceções à imunidade de jurisdição de certos Estados por atos de terrorismo (caso das legislações americana ${ }^{18}$ e canadens $\mathrm{e}^{19}$ ), ou o julgamento de ações indenizatórias ignorando a imunidade de jurisdição em nome do jus cogens (casos da Grécia e da Itália ${ }^{20}$ ). Em síntese, não há normativa internacional convencional ou costumeira admitindo a possibilidade de reparações civis contra Estados soberanos em foro estrangeiro por violações de jus cogens e, simultaneamente, tais normas ainda não foram admitidas como um fundamento per si para o ajuizamento de tais ações.

Considerando novamente a esfera criminal, o Estatuto do Tribunal Penal Internacional (TPI) prevê, em seu preâmbulo, ${ }^{21}$ hipótese geral de exceção à imunidade de jurisdição penal ao definir como de

18 UNITED STATES OF AMERICA. 28 US Code $\int 1605$ A: Terrorism exception to the jurisdictional immunity of a foreign state. Available at: <http://www.law.cornell. edu/uscode/ text/28/1605A >. Last access on: 27 jun. 2014.

19 CANADA. State Immunity Act: An Act to provide for state immunity in Canadian courts. Available at: <http://laws-lois.justice. gc.ca/PDF/S-18.pdf>. Last acess on: 27 jun. 2014. Para exceção à imunidade de jurisdição na hipótese de terrorismo ver o artigo 6.1 .

20 INTERNATIONAL COURT OF JUSTICE. Jurisdictional Immunities of the State (Germanyv.Italy: Greece intervening). Available at: $<$ http: / / www.icj-cij.org/docket/index.php?p1 =3\&p2=3\&case $=14$ $3 \&$ code $=$ ai\&p3 $=4>$. Last access on: 27 jun. 2014.

21 "Relembrando que é dever de cada Estado exercer a respectiva jurisdição penal sobre os responsáveis por crimes internacionais, [...] Sublinhando que o Tribunal Penal Internacional, criado pelo presente Estatuto, será complementar às jurisdições penais nacionais". BRASIL. Decreto 4.388, de 25 de setembro de 2002. Promulga o Estatuto de Roma do Tribunal Penal Internacional. Disponível em: <http:// www.planalto.gov.br/ccivil_03/_decreto/2002/D4388.htm>. Acesso em: 27 jun. 2014. Nesse mesmo sentido: "Furthermore, at the individual level, that is, that of criminal liability, it would seem that one of the consequences of the jus cogens character bestowed by the international community upon the probibition of torture is that every State is entitled to investigate, prosecute and punish or extradite individuals accused of torture, who are present in a territory under its jurisdiction. [...]". INTERNATIONAL CRIMINAL TRIBUNAL FOR THE FORMER YUGOSLAVIA. Trial Chamber. Prosecutor v. Anto Furundrija. Case n. IT-95-17/1-T . Judges Mumba, Cassese \& May. 10 Dec. 1998. Available at: <http:// www. icty.org/x/cases/furundzija/tjug/en/fur-tj981210e.pdf $>$. Last access on: 27 jun. 2014. Parágrafo 156. 
competência interna de cada Estado a persecução daqueles que praticam esses crimes de maior gravidade, sendo a competência penal internacional apenas subsidiária. Da mesma forma, e especialmente no que toca à prática da tortura, a competência do TPI está assentada no artigo $7^{\circ}$ de seu Estatuto, que dispõe sobre os crimes contra a humanidade que envolvem a prática da tortura. ${ }^{22}$ Nesse sentido, podemos citar o Tribunal Criminal Internacional para a ex-Iugoslávia, Tribunal Internacional ad hoc criado pelas Nações Unidas especialmente para os casos de crimes de guerra ocorridos durante os conflitos nos Balcãs, que, ao tratar sobre as questões e implicações da prática da tortura no caso Prosecutor vs Furundzija, reputou serem elas de caráter jus cogens, mesmo que não configurassem propriamente crimes contra a humanidade. ${ }^{23}$

No tocante à exceção à imunidade de jurisdição propriamente dita, temos o Caso Pinochet, no qual, apesar de se tratar da responsabilização pela prática de atos de império, que costumeiramente atraem a incidência da imunidade de jurisdição, o ex-chefe de Estado do Chile, Augusto Pinochet, foi condenado pela Corte Inglesa, pelos fundamentos aduzidos no voto do Excelentíssimo Lord Millet de que a Convenção contra a Tortura, ao proibir a prática desse ato, não criou novo crime na ordem internacional, uma vez que os

22 Art. 7.1(f) Para os efeitos do presente Estatuto, entende-se por "crime contra a humanidade", qualquer um dos atos seguintes, quando cometido no quadro de um ataque, generalizado ou sistemático, contra qualquer população civil, havendo conhecimento desse ataque: Tortura. Art. 7.2(e) Para efeitos do parágrafo 1: Por "tortura" entende-se o ato por meio do qual uma dor ou sofrimentos agudos, físicos ou mentais, são intencionalmente causados a uma pessoa que esteja sob a custódia ou o controle do acusado; este termo não compreende a dor ou os sofrimentos resultantes unicamente de sanções legais, inerentes a essas sanções ou por elas ocasionadas. BRASIL. Decreto 4.388, de 25 de setembro de 2002: Promulga o Estatuto de Roma do Tribunal Penal Internacional. Disponível em: < http:/ / www.planalto.gov.br/ccivil_03/decreto/2002/D4388.htm>. Acesso em: 27 jun. 2014.

23 "Clearly, the jus cogens nature of the probibition against torture articulates the notion that the probibition has now become one of the most fundamental standards of the international community. Furthermore, this probibition is designed to produce a deterrent effect, in that it signals to all members of the international community and the individuals over whom they wield authority that the probibition of torture is an absolute value from which nobody must deviate"; "Although this case does not deal with crimes against humanity, the Trial Chamber finds that this reasoning can also apply to war crimes and other serious violations of international humanitarian law" INTERNATIONAL CRIMINAL TRIBUNAL FOR THE FORMER YUGOSLAVIA. Trial Chamber. Prosecutor v. Anto Furundzija. Case n. IT-95-17/1-T . Judges Mumba, Cassese \& May. 10 Dec. 1998. Available at: <http:/ / www.icty.org/x/cases/furundzija/tjug/en/fur-tj981210e.pdf $>$. Last access on: 27 jun. 2014. Parágrafos 154 e 289.
Estados já estavam proibidos de utilizá-la, mas apenas instituiu um mecanismo para sua efetivação, atribuindo competência criminal a todo e qualquer estado para a persecução do ofensor. Nesta senda, a imunidade de jurisdição ratione materiae seria completamente incompatível com as disposições sobre a tortura presentes na Convenção, já que a imputabilidade do ato ao Estado, ou seja, a sua caracterização como ato oficial, base da concessão de imunidade de jurisdição, é também elemento integrante do conceito de tortura, de forma que a imunidade não poderia ser oposta àquela, cujo sentido é justamente conferir aos demais Estados a obrigação de agir onde a atuação do Estado-ofensor se mostrar digna de reservas, como no caso da persecução de responsabilização por atos emanados de seu poder soberano. $^{24}$

Não obstante o reconhecimento da imperatividade da proibição à prática da tortura, esta consiste exceção à imunidade de jurisdição somente para permitir a persecução criminal dos agentes, não subsistindo nos casos de persecução civil da responsabilização e reparação do dano. Este é o posicionamento reiterado da Comunidade Internacional, explicitado em casos como Schreiber v. Canada ${ }^{25}$, Bouzari v. Iran (Islamic Republic ${ }^{26}$, decididos pela Suprema Corte do Canadá;

24 UNITED KINGDOM. HOUSE OF LORDS. Regina v. Bartle and the Commissioner of Police for the Metropolis and others EX Parte Pinochet (on appeal from a Divisional Court of the Queen's Bench Division) Regina v. Evans and another and the Commissioner of Police for the Metropolis and others EX Parte Pinochet (on appeal from a Divisional Court of the Queen's Bench Division) 37 I.L.M (1998) 1302 reported as R v. Bow Street Metropolitan Stipendiary Magistrate, ex p. Pinochet Ugarte (No 2) sub nom Pinochet Ugarte, Re (1999) UKHL 1 (1999) 1 All ER 577, (1999) 2 WLR 272, 6 BHRC 1, (2000) 1 AC 119, (1999) NLJR 88. Lords Slynn of Hadley, Lloyd of Berwick, Nicholls of Birkenhead, Steyn, Hoffmann. Available at: <http://www.publications. parliament.uk/pa/ ld199899/ldjudgmt/jd990324/pino7.htm> Last access on: 27 junho 2014. Cabe lembrar, nesse interím que o Caso Pinochet afastou a imunidade de jurisdição individual do ex-chefe de Estado, não refletindo, necessariamente na Imunidade do Estado concebido como soberano.

25 CANADIAN SUPREME COURT. Schreiber v. Canada (Attorney General), [2002] 3 S.C.R. 269, 2002 SCC 62. Case nº28453. Judges LeBel, McLachlin, Gonthier, Iacobucci, Bastarache, Binnie, William, Arbour. 12 set 2002. Available at: <http://scc-csc.lexum. com/scc-csc/scc-csc/en/2003/1/document.do> Last access on: 27 jun. 2014.

26 CANADIAN SUPREME COURT. Bouzari v. Iran, 2004 CanLII 871 (ON CA). Case n ${ }^{\circ}$ 38345. Judges Mac Pherson and Cronk. 30 jun 2004. Available at: <http://www. canlii.org/en/on/ onca/doc/2004/2004canlii871/2004canlii871.html> Last aacess on: 27 jun. 2014. 
Al-Adsani v. United Kingdom ${ }^{27}$, Jones and Others v. the United Kingdom ${ }^{28}$, decididos pela Corte Europeia de Direitos Humanos.

O posicionamento do Judiciário canadense, assim, revela consonância com a jurisprudência dominante da Comunidade Internacional em não reconhecer a tortura como exceção à imunidade de jurisdição civil do Estado estrangeiro, mas explicita ao mesmo tempo a dicotomia no que se refere ao tratamento da prática da tortura que, apesar de punível na ultima ratio do Direito ${ }^{29}$, não o é em termos de mera reparação pecuniária.

30 assassinato da Sra. Kazemi não é justiciável, mas o dano causado a seu filho o é: o caso na Quebec Superior Court

\subsection{A proibição da tortura como jus cogens e o Canada State Immunity Act}

Hashemi, em nome próprio e como representante do espólio da Sra. Kazemi, procura a reparação civil pelos danos causados pela prisão, tortura e morte daquela, cuja responsabilidade foi atribuída ao Estado iraniano, na pessoa do Ayatollah Ali Khamenei, e dos altos funcionários do Governo, o Sr. Saeed Mortazavi, Procurador-Geral do Teerã, de quem teria partido a ordem de prisão da Sra. Ziba Kazemi, e o Sr.

27 EUROPEAN COURT OF HUMAN RIGHTS. Grand Chamber. Al-Adsani v. The United Kingdom (ECHR 2001-XI). Case $\mathrm{n}^{\circ}$ 35763/97. Judges Wildhaber, President,. Palm, Rozakis, Costa, Ferrari Bravo, Jörundsson, Caflisch, Loucaides, Cabral Barreto, Jungwiert, Bratza, Zupančič, Vajić,. Pellonpää, Tsatsa-Nikolovska, Levits, Kovler. Available at: <http://hudoc.echr.coe.int/sites/eng/ pages/search.aspx?i=001-59885\# \{“itemid”:[“001-59885”]\}>. Last access on: 27 jun. 2014.

28 EUROPEAN COURT OF HUMAN RIGHTS. Fourth Section. CASE OF JONES AND OTHERS v. THE UNITED KINGDOM

Case $n^{\circ}$ 34356/06 and 40528/06. Judges Ziemele, President, Hirvelä, Nicolaou, Bianku, Kalaydjieva, De Gaetano, Mahoney. 14 jan 2014. Available at: $\mathrm{y}<\mathrm{http}: / /$ hudoc.echr.coe.int/sites/eng/ pages/search.aspx?i=001-140005\#\{“itemid”:[“001-140005”]\}>. Last access on: 27 jun. 2014.

29 "Dizer que a intervenção do Direito Penal é mínima significa dizer que o Direito Penal deve ser a 'ultima ratio, limitando e orientando o poder incriminador do Estado, preconizando que a criminalização de uma conduta somente se justifica se constituir um meio necessário para a proteção de determinado bem jurídico. O Direito Penal somente deve atuar quando os demais ramos do Direito forem insuficientes para proteger os bens jurídicos em conflito". QUEIROZ, Paulo. Sobre a função do juiz criminal na vigência de um direito penal simbólico. IBCcrim, n. 74, 1999. Disponível em: <http://www.ibccrim.org.br/boletim_artigos/9474---Janeiro---1999>. Acesso em: 30 maio 2014.
Mohammad Bakhshi, então Vice-Comandante do setor de inteligência da prisão de Evin, sob cuja custódia teria permanecido a Sra. Kazemi enquanto presa.

A detenção, a prisão, o interrogatório e as torturas irregulares na Penitenciária de Evin, a transferência ao Hospital de Baghiatollah sem a devida notificação à família e o posterior empecilho à sua visitação e ao atendimento e assistência médica auxiliares; sua controversa morte sob custódia iraniana, sua autópsia e seu enterro no Irã contra a vontade da família, não obstante os esforços da Embaixada canadense de repatriação do corpo da Sra. Zahra Kazemi; a ausência de investigações independentes do Governo, a falta de interesse deste em punir os verdadeiros responsáveis e a suposta ausência de prova para condenar o único formalmente acusado, o Sr. Reza Ahmadi, o prejuízo causado pela Sra.Kazemi e por seu filho, o Sr. Hashemi, constituem o arcabouço fático em que se baseou o presente pleito de reparação civil ${ }^{30}$.

Do ponto de vista jurídico, demonstram a possibilidade de responsabilização civil dos requeridos e a competência da corte canadense pela caracterização dos atos por eles praticados como exceções à imunidade de jurisdição prevista no State Immunity Act, vez que inexistente a possibilidade de se ter um julgamento imparcial no Irã, de forma que o caso não se encontrava sob nenhuma jurisdição estrangeira, e o caráter jus cogens da proibição da prática da tortura, que consiste, além de violação aos termos da Convenção Contra a Tortura e outras punições, violação à Carta Canadense de Direitos e Liberdades Individuais e à Constituição Canadense.

O Irã, seu líder, Ayatollah Ali Khamenei, bem como Saeed Mortazavi e Mohammad Bakhshi, por seu turno, levantaram a exceção de incompetência da Justiça canadense para o caso, com base na própria legislação desse país, vez que, nos termos do State Immunity Act (art.3(1) e 3(2) do $S A I)^{31}$, o Irã e seus funcionários gozavam de imunidade de jurisdição no Canadá, nos termos da doutrina da imunidade de jurisdição dos estados

\section{Ver item 2 e subitens.}

31 3. (1) Except as provided by this Act, a foreign state is immune from the jurisdiction of any court in Canada.

Marginal note:Court to give effect to immunity (2) In any proceedings before a court, the court shall give effect to the immunity conferred on a foreign state by subsection (1) notwithstanding that the state has failed to take any step in the proceedings. CANADA. State Immunity Act. An Act to provide for state immunity in Canadian courts. Available at: <http://laws-lois.justice.gc.ca/PDF/S-18. pdf $>$. Last access on: 27 jun. 2014 
soberanos, em relação a seus atos de império, e de seus oficiais (imunidade funcional ou imunidade de jurisdição individual), as quais têm por apanágio teórico a primazia da soberania absoluta, do condicionamento da eficácia das normas de direito internacional à vontade declarada dos Estados e do não reconhecimento de outra vontade externa ou superior a esta.

Aqui, demandantes e demandados já colocam para a Corte canadense o problema da harmonização do direito interno com o direito internacional, na questão da prevalência ou não da imunidade de jurisdição de estados soberanos, principalmente frente à imperatividade das normas de jus cogens, como aquelas de direitos humanos e da prática de tortura, como é o caso.

O direito internacional enfrenta, desde sua origem, o problema do dualismo com o direito interno e da ausência de hierarquia entre suas normas, corolários diretos da concepção clássica de direito e sociedade internacionais, segundo a qual a vontade dos Estados soberanos é a responsável pela caracterização deste como sujeito de direitos e obrigações no plano internacional, isto é, "o Estado é sujeito de direitos e obrigações no plano internacional por sua vontade e desde que livremente consista em se obrigar, assim a vontade passa a ser tida como única fonte do Direito Internacional." "32 Esta caracterização da vontade do Estado como base exclusiva de suas obrigações compõe a chamada teoria da autolimitação do Estado ${ }^{33}$, a qual, apesar de primar pela proteção da soberania estatal, consiste, ao mesmo tempo, ameaça a essa não subordinação a Poder superior, vez que, serve de impulso para que os Estados, com fundamento no mesmo pressuposto do exercício de sua soberania, deixem de cumprir seus acordos e deveres, na mesma medida e com a mesma discricionariedade com que se obrigaram originariamente, em um verdadeiro cenário de insegurança político-jurídica.

Foi justamente fundado nessa proteção à soberania e com vistas ao atendimento das necessidades internas que Napoleão, por exemplo, conquista e invade o território de diversos países europeus, quebrando

32 BYNKERSHOEK, Corneljus Van apud MENEZES, Wagner. Tribunais internacionais: jurisdição e competência. São Paulo: Saraiva, 2013. cap. 1.

33 JELLYNEK, Georgapud VERDROSS, Alfred. O fundamento do direito internacional. Revista de Direito Internacional, v. 10, n. 2, p. 1-33, 2013. Disponível em: <http://www.publicacoesacademicas. uniceub.br/index.php/rdi/article/view/2685>. Acesso em: 23 abr. 2014. acordos de não agressão e cooperação, levando o cenário internacional a um período de instabilidade e insegurança e demonstrando a facilidade de transgressão das normas de direito internacional quando fundadas exclusivamente na vontade dos Estados. Mostrou-se necessário, desta forma, que a proteção da soberania pelo direito internacional fosse deslocada do fundamento da primazia das vontades para o do respeito à própria soberania, aos direitos e garantias mínimos dos outros Estados e seu povo ${ }^{34}$. Apesar dos esforços, a Primeira Grande guerra mundial foi deflagrada, cujos horrores levaram à retificação da necessidade de criação de um conjunto mínimo de direitos a serem respeitados.

Observou-se, então, a necessidade da "existência de um direito internacional geral, oponível a todos os Estados, independentemente de aceitação ou de participação no processo formador das normas, podendo, inclusive, em alguns casos, impor-se aos Estados que sempre se colocaram em objeção a essas normas, é ideia que ganhou curso e é, por muitos, aceita de modo passivo". ${ }^{35}$ Surge assim a noção de jus cogens para o Direito Internacional. Neste ponto, impende registrar que a noção de normas superiores à vontade do próprio Estado não é nova, podendo ser encontrada em doutrinadores como Francisco Suarez, Francisco de Vitória, Grotius e Vattel. A diferença é que aqui essas normas não se fundamentam mais em uma origem divina ou jusnaturalista do direito, mas surgem dentro da própria noção de vontade dos Estados, não mais tomados individualmente, como nos afirma Triepel, mas conjugados em uma comunidade internacional. ${ }^{36}$

34 É o que se pode observar das Conferências de Haia e do Concerto Europeu promovido pelo Congresso de Viena, que buscaram promover um período de paz e equilíbrio hegemônico entre as potências europeias após a queda de Napoleão. A limitação da soberania pelo respeito à própria soberania se fazia presente nas previsões de não intervenção, traduzidas na noção de guerra justa. Nestes termos: "a segunda Conferência de Haia trouxe alguns avanços na decodificação e sistematização do Direito Internacional, no disciplinamento dos aspectos do direito à decretação da guerra (jus ad bellum) e no direito de conduta dos beligerantes durante o estado de guerra (jus in bellum)". CASTRO, Thales. Teoria das relações internacionais. Brasília: FUNAG, 2012. Available at: <http://funag. gov.br/loja/download/931-Teoria_das_ Relacoes_Internacionais. pdf>. Last access on: 30 jun. 2014.

35 NASSER, Salem Hikmat. Jus Cogens: ainda esse desconhecido. Revista Direito GV, v. 1, n. 2, p. 161-178, jun./dez. 2005. Disponível em: <http://bibliotecadigital.fgv.br/dspace/ bitstream/handle/10438/9658/Salem\%20Hikmat\%20Nasser. pdf? sequence $=1>$. Acesso em: 18 maio 2014.

36 VERDROSS, Alfred. O Fundamento do Direito Internacional. Revista de Direito Internacional, v. 10, n. 2, p. 1-33, 2013. 
Dentre as normas desta natureza podem ser identificadas aquelas da ordem pública internacional ${ }^{37}$ como a autodeterminação dos povos, a proibição à guerra de agressão, do uso da força, a imperatividade da busca de soluções pacíficas das controvérsias e os direitos do homem, cuja internacionalização foi acelerada com o fim da Segunda Guerra Mundial ${ }^{38}$, com a Declaração Universal dos direitos do Homem e a oposição dos direitos fundados na dignidade da pessoa humana aos Estados, conferindo aos indivíduos, até então atingidos pelo Direito Internacional apenas quando da internalização destas normas pelo Direito de cada país, a condição de sujeitos de direito internacional. ${ }^{39}$ Apesar desta pretensa anterioridade e reconhecimento geral, a noção de jus cogens só ganha positivação na Convenção de Viena onde se estabelece ser o jus cogens "sinônimo de 'norma(s) imperativa(s) de direito internacional geral' e essas normas são por sua vez definidas como aquelas 'aceita(s) e reconhecida(s) pela comunidade internacional dos Estados como um todo, como norma(s) da(s) qual(is) nenhuma derrogação é permitida e que só pode(m) ser modificada(s) por norma ulterior de Direito Internacional geral da mesma natureza'(art. 53)". 40

É o que se observa, por exemplo, com os direitos humanos, cuja natureza erga omnes encontra azo em sua universalidade, a qual, segundo Flávia Piovesan, lhe é atribuída "porque clama pela extensão universal dos direitos humanos, sob a crença de que a condição de pessoa é o requisito único para a titularidade de

Disponível em: <http://www.publicacoesacademicas.uniceub.br/ index.php/rdi/article/view/2685>. Acesso em: 23 abr. 2014.

37 Aqui, entende-se por ordem pública internacional "o núcleo material intangível da constituição internacional”. TOLEDO JÚNIOR, Milton Nunes. Direito Internacional Imperativo: jus cogens. 2006. 120f. Dissertação (Mestrado em Direito Internacional Econômico)-Universidade Católica de Brasília, Brasília, 2006. Disponível em: <http://www.bdtd.ucb.br/tede/tde_busca/ arquivo.php?codArquivo=285> . Acesso em: 22 maio 2014 .

38 PIOVESAN, Flávia. A Proteção Internacional dos Direitos Humanos das Mulheres. Revista EMERJ, Rio de Janeiro, v. 15, n. 57, Ed. Especial. p. 70-89, jan./mar. 2012. Disponível em: <http:// www.emerj.tjrj.jus.br/ revistaemerj_online/edicoes/revista57/ revista57_70.pdf>. Acesso em: 22 maio 2014.

39 LIMA, Renata Matovani de; ALVES, Renata de Sena. A efetividade do ativismo jurídico transnacional no Sistema Interamericano de Direitos Humanos: uma análise a partir de casos contra o Brasil. Revista de Direito Internacional, Brasília, v. 10, n. 2, p. 239-241, 2013.

40 NASSER, Salem Hikmat. Jus Cogens: ainda esse desconhecido. Revista Direito GV, v. 1, n. 2, p. 161-178, jun./dez. 2005. Disponível em: <http://bibliotecadigital.fgv.br/dspace/ bitstream/handle/10438/9658/Salem\%20Hikmat\%20Nasser. pdf?sequence=1>. Acesso em: 18 maio 2014 . direitos, considerando o ser humano como um ser essencialmente moral, dotado de unicidade existencial e dignidade, esta como valor intrínseco à condição humana". ${ }^{41}$

\section{Assim}

Os direitos humanos são uma expressão direta da dignidade da pessoa humana. A obrigação dos Estados para assegurar a sua observância deriva do reconhecimento desta dignidade, consagrados na da Carta das Nações Unidas e na Declaração Universal dos Direitos Humanos. Esta obrigação internacional, tal como expressa pelo Tribunal Internacional de Justiça, é erga omnes, cabe a cada Estado em relação à comunidade internacional como um todo, e cada Estado tem um interesse jurídico na proteção dos direitos humanos. A obrigação adicional implica um dever de solidariedade entre todos os Estados para assegurar o mais rapidamente possível a efetiva proteção dos direitos humanos em todo o mundo. ${ }^{42}$

Dentro desses direitos encontra-se o direito ao tratamento digno e a consequente proibição à prática de tortura e outras penas degradantes, que se encontram positivados na Convenção das Nações Unidas contra a Tortura e Outros Tratamentos ou Penas Cruéis, Desumanos ou Degradantes (Resolução 39/46 da Assembleia Geral das Nações Unidas), de 10 de dezembro de 1984. Esta, por sua vez, encontra fundamento no artigo $5^{\circ}$ da Declaração Universal dos Direitos do Homem, comungando assim, por arrastamento, de seu caráter erga omnes e de jus cogens.

Esse é o entendimento da Corte Interamericana de Direitos Humanos, expressamente declarado no julgamento do Caso Maritza Urrutia vs. Guatemala,

41 PIOVESAN, Flávia. A Proteção Internacional dos Direitos Humanos das Mulheres. Revista EMERJ, Rio de Janeiro, v. 15, n. 57, Ed. Especial. p. 70-89, jan./mar. 2012. Disponível em: <http:// www.emerj.tjri.jus.br/ revistaemerj_online/edicoes/revista57/ revista57_70.pdf>. Acesso em: 22 maio 2014.

42 Tradução livre do artigo Artigo 1 da Resolução aprovada pelo Institut de Droit International (I.D.I.) na Sessão de Santiago de Compostela de 1989, que dispõe: "Les droits de l'homme sont l'expression directe de la dignité de la personne humaine. L'obligation pour les Etats d'en assurer le respect découle de la reconnaissance même de cette dignité que proclament déjà la Charte des Nations Unies et la Déclaration universelle des droits de l'bomme. Cette obligation internationale est, selon une formule utilisée par la Cour internationale de Justice, une obligation erga omnes; elle incombe à tout Etat vis-à-vis de la communauté internationale dans son ensemble, et tout Etat a un intérêt juridique à la protection des droits de l'bomme. Cette obligation implique au surplus un devoir de solidarité entre tous les Etats en vue d'assurer le plus rapidement possible une protection universelle et efficace des droits de l'homme. Resolução Disponível em: <http://www. idi-iil.org/idiF/resolutionsF/ 1989_comp_03_fr.PDF>. Acesso em: 18 maio 2014. 
para a qual "a proibição da prática da tortura é absoluta e não derrogável, mesmo frente às situações mais difíceis, como a guerra, a ameaça de guerra, a luta contra o terrorismo, e qualquer outro crime, martial law ou estado de emergência, comoção ou guerra civil, suspensão das garantias constitucionais, política interna instável, ou qualquer outro desastre ou emergência pública" ${ }^{\text {"3 }}$. Assim, qualquer matéria relacionada aos direitos do homem com vistas à proteção de sua dignidade consistiria núcleo intocável, imperativo e inderrogável do Direito Internacional, oponível a Estados, Organizações e Indivíduos.

São estes conceitos e afirmações que sustentam as pretensões do Sr. Hashemi em ver condenados e punidos o Estado iraniano e seus funcionários, ante a prática de atos de tortura contra a Sra. Kazemi, levados à sua última consequência, e com os quais pretendem opor e descaracterizar a possibilidade de manutenção da proteção da soberania, especialmente por meio da aplicação de legislações regulamentadoras da imunidade de jurisdição do Estado estrangeiro, fio condutor da exceção de incompetência oposta pelos demandados.

Fundamental na argumentação do governo iraniano a noção de soberania, a qual, embora presente desde a antiguidade, encontra em Bodin sua versão mais acurada. Para este jurista francês, a soberania "é o poder absoluto e perpétuo de uma República". ${ }^{44} \mathrm{Ou}$ seja, "só é soberano, por definição, aquele que em nada depende de outrem, nem do Papa, nem do imperador; que tudo resolve por si mesmo; que não está ligado por vínculo algum de sujeição pessoal; cujo poder não é temporário, nem delegado, nem tampouco responsável perante qualquer outro poder sobre a terra". ${ }^{45}$ A vontade do soberano é, nesta senda, ilimitada e suprema.

43 Tradução livre do trecho: The probibition of torture is absolute and non-derogable, even in the most difficult circumstances, such a war, the threat of war, the fight against terrorism, and any other crime, martial law or state of emergency, civil war or commotion, suspension of constitutional guarantees, internal political instability, or any other public disaster or emergency. CORTE INTERAMERICANA DE DIREITOS HUMANOS. Case of Maritza Urrutia v. Guatemala. Judges Cançado Trindade, President,García Ramírez, Salgado Pesantes, Pacheco Gómez, Abreu Burelli, Roux Rengifo, Martínez Gálvez, 27 nov 2003. Disponível em: <http://www.corteidh.or.cr/docs/casos/articulos/ seriec_103_ing.pdf>. Acesso em: 22 maio 2014

44 Tradução livre do trecho «La souveraineté est la puissance absolue et perpétuelle d'une République..». BODIN, Jean. Les six livres de la republique: livro i, capitulo viii, 1576. Disponível em: <http:// gallica.bnf.fr/ark:/12148/bpt6k6546272j.r=monarchie+de+juillet. langPT>. Acesso em: 18 maio 2014.

45 CHEVALIER, Jean-Jacques. As grandes obras politicas de Maquiavel a nossos dias. 8. ed. Rio de Janeiro: AGIR, 1999. Disponível
Esta noção de poder incondicional, por sua vez, serviu de alimento para a construção de um direito internacional de coordenação, ordenado para a proteção da soberania e emanado desta, onde se funda sua legitimidade ${ }^{46}$ como reconhecido no texto intergovernamental da Paz de Westfália (1648-1659), que conferiu a liberdade, o respeito e o tratamento igualitário aos Estados, por serem estes igualmente soberanos, independente das diferenças que de fato os subjugassem, e foi elevado à categoria de princípio pela Carta das Nações Unidas, norteando todas as disposições de direito internacional desde então até a atualidade.

Criou ainda a condição de irresponsabilidade perante qualquer outro poder, fundada no reconhecimento de que, para haver atribuição de responsabilidade, dever-se-ia necessariamente haver uma relação de subordinação, a qual não existe quando se tem por base uma relação de iguais (coordenação). "Essa regra ficou conhecida, em latim, como par in parem non habet judicium, que quer dizer: não se pode ter jurisdição sobre o par; é necessário ir sempre acima. Uma jurisdição sempre dá a ideia de hierarquia. Ora, quem está acima do rei? Ninguém. Portanto, ninguém tem jurisdição sobre o rei". ${ }^{47}$ Assim, ao não reconhecer outra ordem jurídica que aquela emanada de sua própria soberania, o Estado não reconhece a legitimidade de Tribunais que não constituídos a partir da legislação pátria, ${ }^{48} \mathrm{de}$ forma que não subordinado à sua jurisdição.

Essa noção de imunidade de jurisdição pelo não reconhecimento da competência de jurisdições estrangeiras constitui, ao mesmo tempo, garantia de proteção à soberania de um Estado, que se vê protegido da hipótese de subordinação a outro Poder que aquele emanado de sua Soberania, e limitação à soberania de outro, que se encontra impossibilitado ab initio de

em: <http://mpassosbr.files. wordpress.com/2013/03/as-grandesobras-polc3adticas-de-maquiavel-a-nossos-dias-jean-jacqueschevallier-rio-de-janeiro_-agir-1999.pdf $>$. Acesso em: 18 maio 2014.

46 FINKELSTEIN, Cláudio. Hierarquia das normas no direito internacional: jus cogens e metaconstitucionalismo. São Paulo: Saraiva, 2013. p. 154-155.

47 SOUSA, Mônica Tereza C. Imunidade de Jurisdição de Estado Estrangeiro: aspectos doutrinários e a jurisprudência brasileira. Revista Sequência, Florianópolis, v. 21, n. 40, 2000. Disponível em: <https://periodicos.ufsc.br/index.php/sequencia/article/ view/15442>. Acesso em: 23 maio 2014.

48 BODIN, Jean. Les six livres de la republique: livro i, capitulo viii, 1576. Disponível em: <http://gallica.bnf.fr/ark:/12148/ bpt6k6546272j.r $=$ monarchie + de + juillet.langPT $>$. Acesso em: 18 maio 2014. 
exercer jurisdição plena sobre matérias que considera oportunas de serem submetidas a sua jurisdição. Explica-se: uma vez que não há normas de direito internacional acerca da imunidade de jurisdição de estados soberanos, além daquela que reconhece a sua existência ${ }^{49}$ e imperatividade, os limites de seu exercício ficam, ao alvedrio do direito interno de cada País, o qual, na delimitação de sua competência interna, incluirá as questões relativas aos atos de outra Soberania, se assim o entender cabível. ${ }^{50}$

Nesse ponto, indispensável esclarecer que a discricionariedade toca as questões relativas às exceções à teoria da imunidade de jurisdição e não ao reconhecimento da imposição geral desta, matéria afeta à própria questão de soberania que funda o Direito Internacional moderno, de forma que não se pode conceber uma comunidade internacional organizada nos moldes que hoje se observa, sem a salvaguarda desta imunidade, a qual abrange não só o Estado, mas também seus funcionários e servidores ${ }^{51}$.

Apesar da conveniência da tese da autolimitação do Estado e da reiteração do discurso da irresponsabilidade deste frente às instituições jurídicas de outros, o que se observou ao longo dos anos foi uma mudança de paradigma quanto à inderrogabilidade da imunidade de jurisdição do estado soberano, explicitada na opção pela teoria da imunidade de jurisdição relativa em detrimento da teoria da imunidade absoluta, sendo esta traduzida no brocado latino in parem non babet judicium, ou seja, na total e inderrogável imunidade de Estados Soberanos, que não poderiam ser submetidos em qualquer hipótese à jurisdição estrangeira ${ }^{52}$; e aquela, na mitigação da incidência de referida imunidade, pela

49 SOUSA, Mônica Tereza C. Imunidade de Jurisdição de Estado Estrangeiro: aspectos doutrinários e a jurisprudência brasileira. Revista Sequência, Florianópolis, v. 21, n. 40, 2000. Disponível em: $\quad<$ https://periodicos.ufsc.br/index.php/sequencia/article/ view/15442>. Acesso em: 23 maio 2014.

50 SOUSA, Mônica Tereza C. Imunidade de Jurisdição de Estado Estrangeiro: aspectos doutrinários e a jurisprudência brasileira. Revista Sequência, Florianópolis, v. 21, n. 40, 2000. Disponível em: $\quad<$ https://periodicos.ufsc.br/index.php/sequencia/article/ view/15442>. Acesso em: 23 maio 2014.

51 Nesse sentido: Jeff vs Miller; Jones vs. Ministry of Interior Al-Mamlaka Al-Arabiya AS Saudiya; Samantar vs. Youssef; Bouzari et al v. Islamic Republic, Attorney-General of Canada et al, Intervenors; Al-Adsani v. United Kingdom e Jones v. Kingdom of Saudi Arabia.

52 ACCIOLY, Hildebrando; SILVA, G. E. Nascimento e; CASELLA, Paulo Borba. Manual de direito internacional público. 20. ed. São Paulo: Saraiva, 2012. p. 382. distinção entre atos de império e atos de gestão, sendo somente aqueles, ou seja, os atos em que o Estado atua com vistas à consecução de sua função precípua, hipótese idônea de sua aplicação ${ }^{53}$, teoria atualmente aceita pela comunidade internacional, de forma que a imunidade de jurisdição estatal comporta exceções.

Particularmente, no Canadá, a aceitação desta doutrina encontra-se positivada no State Immunity Act (SIA), o qual reconhece a imunidade de jurisdição dos estados estrangeiros, mas estabelece exceções que determinam a competência das Cortes canadenses para a persecução cível de Estados Soberanos. Nesse sentido, determina o SI $A,{ }^{54}$ a partir de seu artigo $3^{\circ}$ (do Título State Immunity), o reconhecimento da imunidade de jurisdição de Estados estrangeiros frente à Justiça canadense, constituindo exceções a esta garantia a submissão voluntária do Estado estrangeiro (art. $4^{\circ}$ e parágrafos), os atos de gestão (art. $5^{\circ}$ e parágrafos - atividade comercial), suporte ao terrorismo (art. 6 (1)), dentre outros, como o relativo à morte e dano à propriedade, ínsito ao art. $6^{\circ}$, e que dispõe, in verbis:

6. A foreign state is not immune from the jurisdiction of a court in any proceedings that relate to

(a) any death or personal or bodily injury, or

$[\ldots]$

that occurs in Canada.

R.S., 1985, c. S-18, s. 6; 2001, c. 4, s. 121.

Assim, a Corte canadense seria competente para julgar Estados que causassem a morte, o dano pessoal, corporal, ao patrimônio ou a perda de propriedade a qualquer pessoa, desde que estes atos fossem praticados dentro do território canadense (exceção com base na competência territorial).

A dualidade entre a configuração ou não de referidas exceções é o argumento central de autores e réus, reconhecendo os primeiros a não implementação direta destas, mas sua aplicação analógica pela prática de ato contrário à norma jus cogens ${ }^{5}$, e estes, não

53 SOARES, Guido E. Silva; MENDES, Gilmar Ferreira; GARCIA, Márcio Pereira Pinto. Imunidade de jurisdição: evolução e tendências. In: IMUNIDADE soberana: o estado estrangeiro diante do juiz nacional. Brasília: CEJ, 2001. (Série Cadernos do CEJ, v. 19). Disponível em: <http://daleth.cjf.jus.br/revista/seriecadernos/ vol19.pdf>. Acesso em: 23 maio 2014.

54 CANADA. State Immunity act. an act to provide for state immunity in Canadian courts. Available at: < http://laws-lois.justice. gc.ca/PDF/S-18.pdf>. Last access on: 27 jun. 2014.

55 Motion to institute proceedings. parágrafo 108: “The prohibition against torture is a principle of costumary international 
implementação destas hipóteses e o consequente afastamento da jurisdição canadense. Da análise dos fatos e alegações das partes sob a luz do State Immunity Act que emanou o posicionamento da Quebec Superior Court no caso Kazemi, a qual, em decisão da lavra do juiz Robert Mogeon, afastou a competência da Corte no tocante ao espólio da Sra. Kazemi, mas definiu sua competência no tocante aos direitos do herdeiro, o Sr. Stephan (Salman) Hashemi, acolhendo parcialmente as alegações das partes autora e da parte ré.

\subsection{Os danos sofridos pelo herdeiro e a hipótese de competência do art. 6(a) do Canada State Immunity Act}

O Excelentíssimo juiz Robert Mongeon, ao proferir a primeira decisão sobre a admissibilidade do caso Kazemi perante a Corte Canadense, reconheceu a veracidade dos fatos e, quanto ao direito, considerando a validade do SIA em confronto com a Constituição canadense, vez que, em remissão a decisões de casos como Schreiber v. Canada; Bouzari et al v. Islamic Republic, Attorney-General of Canada et al, Intervenors; Al-Adsani v. United Kingdom e Jones v. Kingdom of Saudi Arabia, reconheceu que, no âmbito do ordenamento jurídico canadense, o State Immunity Act estabelece "todos os princípios legais aplicáveis à questão da imunidade de jurisdição do Estado estrangeiro... e, a menos que expressamente atestado em contrário, o SIA contém não apenas o princípio geral da imunidade de jurisdição do estado estrangeiro mas também todas as exceções que podem ser invocadas face a este princípio geral". ${ }^{56}$

law so fundamental and widely acknowledged that it has attained the ststus of a peremptory norm. As jus cogens, it is a requirement that takes precedence over all other laws, be they domestic or international, including those which would provide foreign sovereign immunity. Mr Hashemi therefore pleads that Superior Court of Quebec has jurisdiction to hear this action notwithstanding the provisions of the State Immunity Act, R.S.C. 1985, c. S-18”. ESTATE OF LATE ZAHRA KAZEMU ET AL V. THE ISLAMIC REPUBLIC OF IRAN ET AL. Motion to institute proceedings. par. 108. Disponível em: < http://www.zibakazemi.org/archive/documents/suitqc.pdf>.

56 Tradução livre do trecho; "all of the legal principles applicable to the question of foreign state immunity... and, unless expressly stated otherwise, the SIA contains not only the general principle of foreign state immunity but also contains all of the exceptions which may be invoked against such general principle CANADA. Quebec Superior Court of Justice. Kazemi (Estate of) C. Islamic Republic of Iran, 2011 QCCS 196 (Canlii). Case $\mathrm{n}^{\circ}$ 500-17-031760-062. Judge Robert Mongeon. 26 jan. 2011. par 48. Disponível em: <http://canlii.ca/t/2fh0s $>$. Acesso em: 29 maio 2014.
A análise do caso se restringiu, a partir de então, à possibilidade de configuração das hipóteses de exceção do art. 6(a) ou da aplicação irrestrita do art. $3^{\circ}$. Nesse sentido e citando a decisão e fundamentos do caso Schreiber, o magistrado passou a analisar as implicações da expressão personal injury para a configuração ou não da legitimidade do herdeiro, o Sr. Hashemi ${ }^{57}$.

No tocante ao conteúdo material das exceções previstas no artigo 6(a), remete-se o Excelentíssimo Juiz ao caso Schreiber, no qual a Suprema Corte canadense chegou à conclusão de que, para a configuração da personal injury quando da alegação exclusiva de danos psicológicos, como foi o caso do Sr. Hashemi, estes deveriam se manifestar fisicamente, vez que confrontando o SIA em suas duas versões, a outra conclusão não se poderia chegar:

Tendo por base as provisões da C.C.Q, e as leis relevantes para o caso e a doutrina acima exposta, eu acredito que o conceito no direito civil de 'préjudice corporel-bodily injury', apessar de sua flexibilidade, incorporam uma limitação interna ao âmbito potencial do art. 6(a) da Lei, requerendo uma certa forma de interferência sobre a integridade física. Ainda que os termos 'morte' ou 'lesão pessoal', encontrados na versão inglesa, possibilitem a inclusão de uma lesão não corporal entre as hipóteses de exceção do art. 6(a), os conceitos no direito civil de 'dommages corporels' encontrado na versão francesa do art. 6(a) assim não o faz. Como a versão francesa é a mais clara e mais restritiva das duas versões do art. 6(a), ela melhor reflete a intenção comum do legislador encontrada nas duas versões. ${ }^{58}$

57 Tradução livre do trecho: "Based on the provisions of the C.C.Q, and the relevant case law and doctrine set above, I believe that the civil law concepts of 'préjudice corporel - bodily injury', despite their flexibility, incorporate an inner limitation to potential ambits of s. $6($ a) of the Act, requiring some form of interference with physical integrity. Although the term 'death' or 'personal injury' found in the English version allow the possibility of non-physical injury to be captured within the s. 6(a) exception, the civil law concepsts of 'dommages corporels' found in the French version of s. 6(a) does not. As French version is the clearer and more restrictive version of $s .6(a)$ of the two, it best reflects the common intention of the legislator found in both versions CANADA. Quebec Superior Court of Justice. Kazemi (Estate of) C. Islamic Republic of Iran, 2011 QCCS 196 (Canlii). Case no 500-17-031760-062. Judge Robert Mongeon. 26 jan 2011. par. 68. Disponível em: <http://canlii.ca/ t/2fh0s >. Acesso em: 29 maio 2014.

58 Schreiber v. Canada (Attorney General), [2002] 3 SCR 269, 2002 SCC 62 (CanLII), <http://canlii.ca/t/51rl> retrieved on 2014-06-01 apud CANADA. Quebec Superior Court of Justice. Kazemi (Estate of) C. Islamic Republic of Iran, 2011 QCCS 196 (Canlii). Case $n^{\circ}$ 500-17-031760-062. Judge Robert Mongeon. 26 jan 2011. par. 92. Disponível em: <http://canlii.ca/t/2fh0s >. Acesso em: 29 
A admissibilidade da ação no tocante ao Sr. Hashemi teve, então, por fundamento a possibilidade de configuração, ao longo do processo, das consequências físicas do dano psicológico a ele causado pelo evento morte e aqueles que o antecederam, ${ }^{59}$ determinando, por fim, a subsunção da pretensão do herdeiro à exceção contida no artigo 6(a), nos seguintes termos:

O senhor Hashemi sofreu este prejuízo traumático enquanto residindo no Canadá e isto é suficiente para a aplicação da exceção do artigo 6(a) do SIA. Se o demandante puder provar que o 'trauma' alegado interfere em sua integridade física ou constitui o equivalente a um 'choque nervoso', como elaborado pela Corte canadense no caso Schreiber e Andrusiak, então a imunidade dos demandados será inexistente. A existência, os efeitos e extensão do trauma são questões que deverão ser demonstradas em juízo perante o juiz que se ocupará do mérito da causa. Deste modo, o recurso do Sr. Hashemi não pode ser indeferido no presente estágio de julgamento ${ }^{60}$.

A aplicação destas exceções no tocante às pretensões do espólio, por outro lado, não gerou grandes considerações, vez que todos os danos foram sofridos, não no Canadá (competência territorial), mas no Irã. Assim, a exceção dos réus foi aceita no tocante ao espólio da Sra. Kazemi e rejeitada no que toca seu herdeiro, sendo as pretensões deste recebidas e as daquela rejeitadas.

maio 2014.

59 Schreiber v. Canada (Attorney General), [2002] 3 SCR 269, 2002 SCC 62 (CanLII), <http://canlii.ca/t/51rl> retrieved on 2014-06-01 apud CANADA. Quebec Superior Court of Justice. Kazemi (Estate of) C. Islamic Republic of Iran, 2011 QCCS 196 (Canlii). Case $\mathrm{n}^{\circ}$ 500-17-031760-062. Judge Robert Mongeon. 26 jan 2011. par. 83 e 85. Disponível em: <http://canlii.ca/t/2fh0s>. Acesso em: 29 maio 2014.

60 Tradução livre do trecho "Mr. Hashemi endured this traumatic prejudice while he was resinding in Canada and this is sufficient to trigger the exception in section 6(1) SIA. If the Plaintiff can prove that his alleged 'trauma' touches upon physical integrity or constitues the equivalent of a 'nervous shock' as elaborated by Canadian courts in Schreiber and Andrusiak, then the immunity of the Defendants shall be non-existent. The existence, the effects and depth of his trauma are matters that should be demonstrated at trial before the judge seized of the merits of the case. Accordingly, the recourse of Mr. Hashemi cannot be dissmissed at this stage". CANADA. Quebec Superior Court of Justice. Kazemi (Estate of) C. Islamic Republic of Iran, 2011 QCCS 196 (Canlii). Case $n^{\circ}$ 500-17-031760-062. Judge Robert Mongeon. 26 jan 2011. Disponível em: <http://canlii.ca/t/2fh0s $>$. Acesso em: 29 maio 2014 .Par. 92.

\section{0 dano causado ao herdeiro não permite fixar a jurisdição canadense: 0 caso na Quebec Court of Appeal}

\subsection{A Constituição canadense interpretada à luz do jus cogens: razões para indenizar o espólio}

Inconformados com a decisão, autores e réus apelam à Quebec Court of Appeal da decisão supra analisada com base respectivamente na inconstitucionalidade do SIA frente a Canadian Bill of Rights and Freedoms, o Canadian Charter of Rights and Freedoms, e a Convention Against Torture and other Cruel, Inbuman or Degrading Treatment or Punishment; e na não configuração das hipóteses de exceção do art. 6(a), pela simples alegação de dano moral, o que será objeto do próximo tópico.

A pretensa inconstitucionalidade encontra azo no obstáculo imposto pelo SIA a um devido processo legal no caso Kazemi, vez que, em não tendo havido qualquer investigação ou responsabilização por parte das autoridades iranianas no Irã, a admissibilidade da reclamação pela Corte canadense constituiria o único meio para se alcançar referidas reparações e responsabilizações. Nesse ínterim, em não admitindo sua competência, o Estado canadense estaria corroborando com as atrocidades levadas a feito pelo Irã, em clara violação a dispositivos constitucionais.

Desta forma a garantia da imunidade de jurisdição do estado estrangeiro entraria em confronto direto com o art. 2 da Bill of Rights ${ }^{61}$, que prevê o direito ao

61 "BILL OF RIGHTS- Art2. Every law of Canada shall, unless it is expressly declared by an Act of the Parliament of Canada that it shall operate notwithstanding the Canadian Bill of Rights, be so construed and applied as not to abrogate, abridge or infringe or to authorize the abrogation, abridgment or infringement of any of the rights or freedoms herein recognized and declared, and in particular, no law of Canada shall be construed or applied so as to

(a) authorize or effect the arbitrary detention, imprisonment or exile of any person;

(b) impose or authorize the imposition of cruel and unusual treatment or punishment;

(c) deprive a person who has been arrested or detained

(i) of the right to be informed promptly of the reason for his arrest or detention,

(ii) of the right to retain and instruct counsel without delay, or

(iii) of the remedy by way of habeas corpus for the determination of the validity of his detention and for his release if the detention is not lawful;

(d) authorize a court, tribunal, commission, board or other authority to compel a person to give evidence if he is denied counsel, protection against self crimination or other constitutional safeguards;" CANADÁ. Canadian Bill of Rights (S.C. 1960, c. 44). Disponível em: <http://laws-lois.justice.gc.ca/eng/acts/c-12.3/ page-1.html>. Acesso em: 18 maio 2014. 
devido processo legal, o art. 7 da Carta canadense ${ }^{62}$, que prevê a proteção da pessoa humana e a Convenção contra a Tortura ${ }^{63}$ como um todo, por não implementar seus objetivos e fundamentos de vedação à pratica da tortura.

Pretendem, então, os autores que as normas canadenses sejam aplicadas sob a luz dos valores reconhecidos pela soberania canadense, em especial aqueles fundados em normas internacionais cogentes, como a Convenção Contra a Tortura para que se declare a infringência pelo art. $3^{\circ}$ do State Immunity Act aos arts. $2^{\circ}$ da Bill of Rights e $3^{\circ}$ da Carta canadense e sua consequente inconstitucionalidade.

A Quebec Court of Appeal, na análise da constitucionalidade do SIA, reafirma sua completude no tocante às exceções previstas, não constituindo o costume internacional e as normas de jus cogens, instrumentos suficientes para sua ampliação, direito reservado à manifestação soberana do Estado através de seu legislativo. Atesta sua constitucionalidade e compatibilidade com dispositivos da Bill of Rights e da Charter, vez que as determinações fundadas nestas dizem respeito à implementação das garantias já asseguradas por lei. Assim, aqueles dispositivos não criam novos direitos para além daqueles legalmente previstos, mas asseguram o regular cumprimento deste.

Nesta senda, e tendo por base os julgamentos da matéria em casos como Schreiber, v. Canada (Attorney General), Daniel v White, Bouzari v Islamic Republic of Iran, aduzem os juízes da Court of Appeal a completude do SIA em três argumentos principais: a

62 "Charter of rights and freedoms- Art. 7 . Everyone has the right to life, liberty and security of the person and the right not to be deprived thereof except in accordance with the principles of fundamental justice". CANADÁ. Constitution Act, 1982 (80) Part I: Canadian Charter of Rights and Freedoms. Disponível em: <http:/ / laws-lois.justice.gc.ca/eng/Const/page-15.html?texthighlight $=$ canadian charter of rights and freedoms\#inc $>$. Acesso em: 18 maio 2014

63 “Convenção Contra a Tortura - Art. 14 1. Each State Party shall ensure in its legal system that the victim of an act of torture obtains redress and has an enforceable right to fair and adequate compensation, including the means for as full rehabilitation as possible. In the event of the death of the victim as a result of an act of torture, his dependants shall be entitled to compensation. 2 . Nothing in this article shall affect any right of the victim or other persons to compensation which may exist under national law". ONU. Convenção das Nações Unidas contra a Tortura e Outros Tratamentos ou Penas Cruéis, Desumanos ou Degradantes (Resolução 39/46 da Assembleia Geral das Nações Unidas), de 10 de dezembro de 1984. Disponível em: http://bvsms.saude.gov.br/bvs/publicacoes/conv_contra_tortura. pdf. Acesso em: 22 maio 2014. expressão "except as provided by this Act"/ "Sauf execptions prévues dans la présente loi"; a ausência de ambiguidade genuína a permitir uma interpretação das disposições com base nos princípios e valores a ele externos; e a consequente prevalência do direito interno em caso de conflito com o internacional.

\section{Quanto a essa prevalência explica que}

Em casos como o presente, onde um estatuto contém previsão clara e inconsistente com princípios vinculadores do Costume internacional, esta previsão poderá, nas palavras do juiz LeBel no caso Hape 'violar a lei internacional e ofender as cortesias recíprocas entre as nações', mas o Parlamento, no exercício de sua soberania tem o poder de legislar desta forma'. E continua: '... as exceções à imunidade de jurisdição dos Estados no direito positivo canadense são aquelas previstas no SIA, não em algum remanescente de uma hipotética doutrina de commom law que coexistiria com a Lei, ou em alguma regra do direito internacional costumeiro que modularia a interpretação de uma disposição legal que na verdade não precisa de interpretação. Tal norma de direito internacional costumeiro, se existisse, poderia ter sido facilmente integrada ao SIA por meio de uma emenda, mas o Parlamento assim não o fez ${ }^{64}$.

Cita, por fim, a decisão da Corte Internacional de Justiça sobre o caso Germany v. Italy, de 3 de fevereiro de 2012, no qual a República da Alemanha representou contra a República Italiana (Corte di Cassaz̧ione) perante a Corte Internacional pela não aplicação da garantia internacional da Imunidade de Jurisdição ao Estado alemão quando do julgamento de casos de violação de direitos internacionais perpetuados por esta, enquanto

64 Tradução livre do trecho "Where as here a statute contains a provision which is clear and is inconsistent with binding principles of customary international law, this provision may, in words of justice LeBel in Hape, 'violate international law and offend the comity of nations', but Parliament in the exercise of its sovereignty does have the power to enact in that form." E continua: "... the exceptions to state immunity in Canadian positive law are those set out in the SLA, not in some remnant of a bypothetical common law doctrine that would coexist with the Act, or in some rule of customary international law that might modulate the interpretation os a statutory phrase which in fact is in no need of interpretation. Such a rule of customary international law, if it existed, could easily have been integrated in the SLA by a legislative amendment but Parliament did not so." CANADA. Quebec Court of Appeal. Islamic Republic of Iran C. Hashemi, 2012 QCCA 1449. Case no 500-09-021440-110. Judges Yves-Marie Morissette, Richard Wagner, Clément Gascon. 15 ago. 2012. par. 41. Disponível em: <http://www.jugements.qc.ca/php/decision. php?liste $=76814341 \&$ doc $=2 B 1951 \mathrm{E} 730 \mathrm{AB} 4 \mathrm{~F} 1 \mathrm{BFC} 7 \mathrm{DE} 8781 \mathrm{E}$ 40C2D3A534A6207CECDBF438486FE01E90FD30\&page $=1>$. Acesso em: 29 maio 2014. 
nazista, nos territórios da Itália e da Grécia. A CIJ, apesar de reconhecer a atrocidade e ilegalidade dos atos, explicitou a ausência de autonomia entre as normas de jus cogens e a regra da imunidade de jurisdição, vez que atuariam em planos diferentes do Direito: esta é estritamente processual, apenas determina a competência jurisdicional do Estado, sem que seja necessário um juízo de valor sobre as condutas por ela abrangidas para a determinação de sua validade, o que não ocorreria com o direito material de acordo com o argumento de injustiça de Alexy. ${ }^{65}$

Superada a questão da completude, passam a analisar a implementação da hipótese de fixação de competência ínsita ao art. 6(a) em relação ao herdeiro da Sra. Kazemi (a ser analisado no tópico seguinte), e, logo em seguida, ocupam-se da questão da compatibilidade do SIA com a Canadian Bill of Rights, com a Canadian Charter of Rights and Freedoms e sua consequente constitucionalidade.

A constatação da compatibilidade da garantia da imunidade de jurisdição prevista no art. $3^{\circ}$ do State Immunity Act com a previsão de um devido processo legal do art. $2^{\circ}$ da Canadian Bill of Rights teve por fundamento os mesmos argumentos levantados no caso Aristocrat v. National Bank of the Republic of Kazakhstan e no Authorson v Canada (Attorney General), de que não haveria violação ao art. $2^{\circ}$ da Bill of Rights porque este cuida da responsabilidade do Estado canadense no tocante aos atos perpetrados por aqueles que sob seu imperium.

Nesta senda, em não havendo esta subjugação ao Poder Estatal, não haveria que se falar em aplicação do respectivo art. $2^{\circ}$ da Bill of Rights: "A Seção 2(e) da Bil of Rights não impõe ao Parlamento o dever de assegurar a audiência dos interessados antes da promulgação de uma lei. Suas proteções só são operantes na aplicação do direito a circunstâncias individuais no procedimento perante a Corte, Tribunal ou similares". ${ }^{66}$.

65 ALEXY, Conceito e validade do direito. 2. ed. Tradução Gercélia Batista de Oliveira Mendes. São Paulo: WMF Martins Fontes, 2011. p. 48 e ss.

66 Tradução livre do trecho: "Section 2(e) of the Bill of Rights does not impose upon Parliament the duty to provide a bearing before enactment of legislation. Its protections are operative only in the application of law to individual circumstances in a proceeding before a court, tribunal or similar body” CANADA. Quebec Court of Appeal. Islamic Republic of Iran C. Hashemi, 2012 QCCA 1449. Case no 500-09-021440-110. Judges Yves-Marie Morissette, Richard Wagner, Clément Gascon. 15 ago 2012. par. 107. Disponível em: <http://www.jugements.qc.ca/php/ decision. $\quad$ php?liste $=76814341 \&$ doc $=2 B 1951 \mathrm{E} 730 \mathrm{AB} 4 \mathrm{~F} 1 \mathrm{BFC} 7 \mathrm{D}$ E8781E40C2D3A534A6207CECDBF438486FE01E90FD30\&pa ge $=1>$. Acesso em: 29 maio 2014 .
A compatibilidade com o art. $7^{\circ}$ da Charter, no que este dispõe sobre o direito à liberdade de escolha, tomada pelos autores como liberdade de buscar a reparação pelo dano sofrido, encontra azo nos mesmos fundamentos de que ali se asseguram a efetividade de direitos já concedidos e reconhecidos e na medida em que estes se implementaram:

Há inúmeras normas procedimentais no Canadá, e também algumasmatérias, que determinam quem pode ser processado, por quem, quando e onde. Quer de direito ou de fato, essas normas limitam, e por vezes até precluem (como no caso dos litigantes de má-fé), a possibilidade de se trazer a juízo uma ação na forma que se bem entender. A ideia de que essas normas infrigem um 'direito de processar' ínsito ao art. $7^{\circ}$ da Carta me parece altamente problemático. ${ }^{67}$

Assim, não reconhecendo a incompletude do SIA ou sua incompatibilidade com as disposições da Canadian Bill of Rights e da Canadian Charter of Rights and Freedoms, a Corte de Apelação rejeita o primeiro bloco de argumentos dos Plaintiffs, acolhendo, por conseguinte, as pretensões de apelação dos Defendants.

\subsection{Dano moral não configura a hipótese de competência do art. 6(a) do Canada State Immunity Act: a reversão da decisão da Quebec Superior Court}

O acolhimento da competência da Justiça canadense para julgar as pretensões do Sr. Hashemi com base na alegação de que a configuração dos efeitos físicos do dano sofrido deveria ser objeto da análise do mérito, dispensável, portanto, em um juízo sumário de admissibilidade, foi considerada imprópria pela República Islâmica do Irã e demais demandados.

Isso porque, para eles, não houve ab initio, a configuração da hipótese de fixação de competência do art. 6(a) do State Immunity Act, como foi até mesmo

67 Tradução livre do trecho "There are several sets of procedural rules across Canada, and some substantive rules as well, which determine who can be sued, by whom, when and where. Whether de jure or de facto, these rules limit, and sometimes preclude altogether (for example in the case of persistently vexatious litigants), the possibility of bringing an action exactly as one might wish. The idea that such rules may all amout to potencial infrigements of a 'right to sue' subsumed under s. 7 of the Charter strikes me as highly problematic" CANADA. Quebec Court of Appeal. Islamic Republic of Iran C. Hashemi, 2012 QCCA 1449. Case no 500-09-021440-110. Judges Yves-Marie Morissette, Richard Wagner, Clément Gascon. 15 ago 2012. par. 119. Disponível em: <http://www.jugements.qc.ca/php/decision. php?liste $=76814341 \&$ doc $=2 B 1951 \mathrm{E} 730 \mathrm{AB} 4 \mathrm{~F} 1 \mathrm{BFC} 7 \mathrm{DE} 8781 \mathrm{E}$ 40C2D3A534A6207CECDBF438486FE01E90FD30\&page $=1>$. Acesso em: 29 maio 2014. Nota rodapé 107. 
reconhecido pelos autores em sua inicial, vez que intentaram a reparação não pela subsunção de sua situação às hipóteses de exceção previstas no SIA, mas a uma interpretação analógica destas com vistas a ampliar sua aplicação frente os casos de violação a normas de jus cogens. Nesse sentido sustentam ter havido dano apenas indireto e reflexo, de forma que o dano principal em que fundada a ação ficou adstrito ao território iraniano. Por outro lado, o senhor Hashemi em momento algum alegou a consequência física de seus danos psicológicos, constituindo-se em meros danos morais, a exemplo do que ficou decidido no caso Schreiber.

A Corte de Apelação, analisando os conceitos dos termos trazidos pelo art. 6(a) do SIA, e tendo por base os entendimentos esposados em outras decisões similares, decidiu por acolher as pretensões do recurso dos réus para afastar a incidência da Jurisdição canadenses relativamente às pretensões do Sr. Hashemi, por não encontrar em suas alegações base para a configuração de dano físico além dos meramente morais efetivamente demonstrados.

Assim, no que toca à expressão "personal or bodily injury"/ "dommages corporels", a Court of Appeal repete o entendimento do juiz de primeiro grau ${ }^{68}$ no sentido de ser necessária a somatização do dano psicológico, demonstrando claro prejuízo físico ao herdeiro, mas reforma àquela, com base nos casos Greco v. Holy SEE (State of Vatican City), P.(R.) v. Westwood, Ritter v. Donell and Castle v. United State Department of Justice (Attorney general), nos seguintes termos:

... as alegações relevantes do pleito do sr. Hashemi se referem meramente a noções gerais de trauma, prejuízo psicológico e emocional. O juiz de primeiro grau ponderou que esse alegação de trauma poderia, no fim das contas, ter interferido na integridade física do Sr. Hashemi e que em juízo poderia ser evidenciado o dano corporal como resultado. Opinou então que isso era suficiente para permitir que o pleito fosse admitido para julgamento. Eu respeitosamente discordo. Mesmo considerando os fatos como sustentado, as alegações do Sr. Hashemi não conseguem explicitar um prejuízo à integridade física; deste modo, elas falham em demonstrar o cabimento da exceção prevista no art. 6(a). Teria sido fácil para o Sr. Hashemi expor devidamente a

68 Remete-se o leitor à discussão feita no item 3.2 sobre a adequação dos significados das disposições do SIA em inglês e aquelas em francês para que se pudesse chegar à real vontade do legislador. extensão, se houvesse alguma, do prejuízo à integridade física que teria sofrido. Contudo, ele preferiu não fazêlo. Era dele, entretanto, o ônus de provar que a exceção do art. 6(a) se aplicaria ao caso em tela ${ }^{69}$.

Assim, refutando os últimos argumentos dos Plaintiffs, a Quebec Court of Appeal, rejeita o recurso do espólio de Kazemi, dá provimento ao da República Iraniana, Ayatollah Sayd Ali Khamenei, Saeed Mortavazi e Mohammad Bakhshi para rejeitar a ação contra estes intentada pelo herdeiro, o Sr. Hashemi, em consonância com o reiterado posicionamento da jurisprudência canadense de não configuração de exceção à imunidade de jurisdição a infringência às normas que vedam a prática da tortura, ainda que importem na violação de normas de jus cogens.

\section{A limitação à responsabilização patrimonial do estado estrangeiro pela prática de atos de tortura não afronta a sociedade democrática de direito: 0 caso na Supreme Court of Canada}

Inconformados com a negativa geral da Court of Appel, o Sr. Hashemi e o espólio da Sra. Kaz̧emi desafiaram a constitucionalidade do SIA, frente às disposições da Charter e da Bill of Rights canadenses. Em 17 de outubro de 2014, após quase 2 anos de um longo e desgastante processo, e sem um posicionamento unânime, a Suprema Corte do Canadá proferiu a decisão final para o Caso Kazemi, ratificando o posicionamento do Estado canadense acerca da aplicabilidade da imunidade de jurisdição frente à prática de atos de tortura ${ }^{70}$.

69 Tradução livre do trecho: ““'.... the relevant allegations of $M r$. Hashemi's claim merely refer to general notions of trauma, psychological and emotional prejudice. The motion judge noted that this alleged trauma may, in the end, touch upon Mr. Hashemi's physical integrity and that the evidence at trial may indicate the suffere bodily injury as result. He therefore opined that this was suffucuent to allow the claim to go to trial. I respectfully disagree. Even if taken as averred, the allegations of $\mathrm{Mr}$. Hashemi's claim fall short of establishing any breach of physical integrity; accordingly, they fail to bring into play the exception set out in s. 6(a). It would have been easy for Mr. Hashemi to properly articulate the extent, if any, of the breach of physical integrity that he may have suffered. Still, he elected noto to do so. He had, after all, the burden of establishing that the s. 6(a) exception applied here". CANADA. Quebec Court of Appeal. Islamic Republic of Iran C. Hashemi, 2012 QCCA 1449. Case $\mathrm{n}^{\circ} 500-$ 09-021440-110. Judges Yves-Marie Morissette, Richard Wagner, Clément Gascon. 15 ago 2012. par. 84. Disponível em: <http:// www.jugements.qc.ca $/ \mathrm{php} /$ decision.php?liste $=76814341 \& \mathrm{doc}=2 \mathrm{~B}$ 1951E730AB4F1BFC7DE8781E40C2D3A534A6207CECDBF43 8486FE01E90FD30\&page=1>. Acesso em: 29 maio 2014.

70 CANADA. Supreme Court of Canada. Estate of the Late Zabra (Ziba) Kazemi, et al. v. Islamic Republic of Iran. Available at: <http://www.scc-csc.gc.ca/case-dossier/info/sum-som-eng. aspx?cas $=35034>$. Last access on: 29 mai 2014 . 
5.1 Hipóteses de exceção à imunidade de jurisdição e a qualificação da prática de tortura como ato oficial do Estado: impedimentos infraconstitucionais à desconsideração da imunidade de jurisdição.

Antes de adentrar especificamente na questão da constitucionalidade do SIA e como pressuposto para a resolução desta, a Suprema Corte canadense se dignou a analisar todos os argumentos até então trazidos pelas partes e pelas instâncias anteriores.

$\mathrm{O}$ primeiro argumento enfrentado foi o que diz respeito à completude do SIA no que toca à regulamentação da matéria de imunidade de jurisdição, ponto mais afeito ao conflito imunidade de jurisdição versus a violação de norma jus cogens, no qual se perquiriu se a incontestável peremptoriedade da proibição da prática de atos de tortura era condição suficiente para a criação de uma jurisdição cível universal e para a criação de uma exceção cogente e erga omnes à imunidade de jurisdição.

A Corte enfrentou de início o problema da completude do SIA, que, não prevendo a prática de atos de tortura em sentido amplo, estaria, segundo a tese dos autores, defasado frente à evolução do Direito Internacional e do sistema de proteção da pessoa e dos direitos humanos. Para a Corte, conforme voto do relator, ministro LeBell, a questão da imunidade de jurisdição é questão atinente ao direito processual interno, fruto da cortesia, costume internacional e política interna, de forma que apenas o Legislativo, como detentor do Poder de dizer a vontade do Povo, é competente para impor-lhe exceções. Nesse sentido, o Parlamento canadense escolheu o critério da territorialidade para fixar sua jurisdição, inclusive quando um dos elementos da ação for o Estado estrangeiro.

Com isso, a interpretação da suposta "lacuna" do SIA foi no sentido diametralmente oposto àquele sustentado pelos autores, posto que se traduz na proposital não previsão desta exceção. Assim, a completude do SIA emana da própria inexistência de mobilização deste Poder para a inclusão da tortura praticada no estrangeiro como hipótese de exceção à imunidade de jurisdição, bem como da inexistência de uma jurisdição cível universal para casos como o Kazemi ${ }^{71}$. Ainda nesse

71 CANADA. Supreme Court of Canada. Estate of the Late Zabra (Ziba) Kazemi, et al. v. Islamic Republic of Iran, et al. Available at: <http://www.scc-csc.gc.ca/ case-dossier/info/ sum-som-eng. aspx?cas $=35034>$. Last access on: 29 mai 2014 . sentido, é a análise da possibilidade de configuração da hipótese 6(a) em relação ao dano psicológico sofrido pelo Sr. Hashemi, na qual a Corte Suprema reitera o posicionamento da Court of Appeal ${ }^{2}$, retomando e reafirmado a questão da territorialidade da jurisdição canadense e da interpretação do SIA como resultado da manifestação da vontade e opção políticas do Estado. ${ }^{73}$

A Corte seguiu ainda o voto do relator, sendo dissidente a ministra Abella J., no sentido de que, sendo a tortura, na forma em que concebida pelo artigo $1^{\circ}$ da Convenção contra a tortura e outros tratamentos ou penas cruéis desumanos ou degradantes $(1984)^{74}$, um ato tipicamente de Estado, insofismável a incidência da imunidade de jurisdição do estado estrangeiro nos casos em que presentes os atos de tortura, posto que emanados da Soberania estatal. A incidência do instituto se dá, ainda, da forma mais abrangente possível, conglobando os oficiais, que, nesta qualidade, e agindo como longa manus do Estado, levaram a feito os atos cruéis, posto que seus atos são emanação da própria vontade do Estado $^{75}$.

Assim, configuradas a completude do SIA, a caracterização da tortura com ato de império e afastadas as hipóteses de configuração de exceção à imunidade de jurisdição, chegou a Corte à conclusão de que a desconsideração da imunidade de jurisdição do estado estrangeiro ante a prática de atos de tortura não encontra arrimo na legislação infraconstitucional,

72 Remete-se o leitor ao subitem 4.2 do presente trabalho.

73 CANADA. Supreme Court of Canada. Estate of the Late Zabra (Ziba) Kazemi, et al. v. Islamic Republic of Iran. Available at: $<$ http://www.scc-csc.gc.ca/case-dossier/info/sum-som-eng. aspx?cas $=35034>$. Last access on: 29 mai 2014.

74 Convenção contra a tortura e outros tratamentos ou penas degradantes (1984), art. 1: "Para os fins da presente Convenção, o termo "tortura" designa qualquer ato pelo qual dores ou sofrimentos agudos, físicos ou mentais, são infligidos intencionalmente a uma pessoa a fim de obter, dela ou de uma terceira pessoa, informações ou confissões; de castigá-la por ato que ela ou uma terceira pessoa tenha cometido ou seja suspeita de ter cometido; de intimidar ou coagir esta pessoa ou outras pessoas; ou por qualquer motivo baseado em discriminação de qualquer natureza; quando tais dores ou sofrimentos são infligidos por um funcionário público ou outra pessoa no exercício de funções públicas, ou por sua instigação, ou com o seu consentimento ou aquiescência. Não se considerará como tortura as dores ou sofrimentos que sejam conseqüência unicamente de sanções legítimas, ou que sejam inerentes a tais sanções ou delas decorram". Disponível em: <http://bvsms.saude.gov.br/bvs/ publicacoes/conv_contra_tortura.pdf $>$. Acesso em: 22 maio 2014

75 CANADA. Supreme Court of Canada. Estate of the Late Zabra (Ziba) Kazemi, et al. v. Islamic Republic of Iran. Available at: <http://www.scc-csc.gc.ca/case-dossier/info/sum-som-eng. aspx?cas $=35034>$. Last access on: 29 mai 2014. 
de forma que necessário o enfrentamento do desafio constitucional.

\subsection{A limitação ao direito de reparação em casos de tortura é compatível com a sociedade democrática de direito: a constitucionalidade do SIA.}

A argumentação da Corte Suprema no que tange à constitucionalidade do $S A I$ parte do pressuposto de que nenhuma norma canadense poderá ser interpretada ou aplicada de modo a negar ao indivíduo o acesso à justiça. Esse pressuposto, contido na seção 2(e) do Bill of Rights canadense, parece desafiado pelas disposições relativas à imunidade, formando uma barreira procedimental à realização da justiça. Tal linha argumentativa foi combatida pela Advocacia Geral do Canadá, arrazoando que o Bill só protegeria direitos que já existissem quando de sua promulgação em 1960, o que não é o caso do direito de processar um Estado estrangeiro, visto que a imunidade de jurisdição, na época, era absoluta. Além disso, o direito contido na seção 2(e) consiste em um direito procedimental que só pode existir no seio de um processo judicial e, como não é possível instituir um processo judicial no caso Kasemi, o dispositivo não é aplicável. O relator do caso posicionou-se de acordo com a Advocacia Geral, acrescentando que a seção 2(e) não cria um direito autônomo de acesso a justiça quando a lei não autoriza a formação de um processo. ${ }^{76}$

A seguir, foi abordada a questão da compatibilidade do artigo 3(1) o do SIA com o artigo 7 da Canadian Charter of Rights and Freedoms. $\mathrm{O}$ teste em questão envolveu elucidar se a imunidade de jurisdição, na forma como disposta na legislação canadense, implica em uma limitação à segurança de indivíduos e, portanto, tem potencial para ofender a Carta. $\mathrm{O}$ arrazoado partiu da afirmativa dos recorrentes de que o artigo 3(1) amplia o sofrimento dos indivíduos ao impedir que estes busquem reparação após um membro de sua família haver sido torturado e que tal sofrimento vai muito além da ansiedade comum ocasionada pelas vicissitudes da vida. Em seguida, introduziu a posição do Advogado Geral do Canadá, pela qual o artigo 7 não é aplicável à questão, uma vez que o senhor Hashemi limitou-se a alegar que sofreu dano psicológico decorrente da

76 CANADA. Supreme Court of Canada. Estate of the Late Zahra (Ziba) Kazemi, et al. v. Islamic Republic of Iran. Available at: <http://www.scc-csc.gc.ca/case-dossier/info/sum-som-eng. aspx?cas $=35034>$. Last access on: 29 mai 2014. tortura sofrida por sua mãe e da impossibilidade de buscar compensação no Irã, e não dano decorrente da impossibilidade de processar o Irã no Canadá, acrescentando ainda que não há evidência de que a interdição de um processo civil impeça a reabilitação de vítimas de tortura e afirmando, por fim, que o dano sofrido pelo Sr. Hashemi não foi nem profundo nem sério, como exigido pelo artigo $7 \mathrm{da}$ Charter. Por fim, o relator introduziu a perspectiva dos intervenientes, de que o direito internacional provê fundamento aos pedidos do Senhor Hashemi, em particular à alegação de que o artigo 3(1) do SIA causou a ele um trauma psicológico e que há substancial jurisprudência internacional no sentido de que a negativa de acesso à reparação em casos de tortura causa dano psicológico, no caso em questão, o dano seria tão severo que envolveria a violação do artigo 7 da Charter?

Emseguida, orelatorpassou àanálise dos argumentos apresentados, considerando inicialmente que a ação estatal envolve a segurança da pessoa quando possui impacto em sua integridade psicológica individual, sendo que esse impacto deve ser grave, profundo e seus efeitos objetivamente verificáveis. Além disso, tais danos graves, profundos e objetivamente verificáveis devem apresentar uma suficiente conexão causal entre o dano psicológico e as ações do Estado, de modo a permitir afirmar que o dano foi resultante da ação do Estado. O relator admitiu que a impunidade por tortura pode causar significativo dano psicológico à vítima e a seus familiares, posição esta que encontra suporte na jurisprudência internacional, da qual destacou a da Corte Interamericana de Direitos Humanos. Ele ponderou que seria preferível que esse dano tivesse sido verificado pericialmente na fase de instrução, mas que isso não seria razão a obstar a discussão. Observou ainda que não é evidente a equiparação entre ausência de reparação civil devida à imunidade de jurisdição do Estado e impunidade, no entanto, reconheceu que o interesse em obter uma resposta final após um ato de tortura toca aspectos cruciais da dignidade humana ${ }^{78}$.

Com relação ao nexo de causalidade, o relator apontou que sua configuração não exige que o Estado

77 CANADA. Supreme Court of Canada. Estate of the Late Zabra (Ziba) Kazemi, et al. v. Islamic Republic of Iran. Available at: $<$ http://www.scc-csc.gc.ca/case-dossier/info/sum-som-eng. aspx?cas $=35034>$. Last access on: 29 mai 2014.

78 CANADA. Supreme Court of Canada. Estate of the Late Zabra (Ziba) Kazemi, et al. v. Islamic Republic of Iran. Available at: <http://www.scc-csc.gc.ca/case-dossier/info/sum-som-eng. aspx?cas $=35034>$. Last access on: 29 mai 2014. 
seja o único ou mesmo o principal causador do dano sofrido pelas vítimas. Ou seja, embora a razão imediata do dano psicológico causado ao senhor Hashemi tenha sido a tortura da qual sua mãe foi vítima no Irã, isso não elimina necessariamente qualquer papel do Canadá em seu sofrimento. No entanto, embora seja possível, na visão do relator, que a aplicação do artigo 3(1) do SIA possa causar prejuízos psicológicos relevantes, capazes de ameaçar a segurança das pessoas, ele não considerou necessário decidir se o dispositivo está em conflito com a Canadian Charter, pois sua aplicação não viola nenhum princípio fundamental de justiça ${ }^{79}$.

O relator a seguir explicita que, para haver uma violação do artigo 7 da Canadian Charter, é necessário que se demonstre que um princípio fundamental de justiça foi violado devido à aplicação do artigo 3(1) do SIA.

Os apelantes alegam que isso ocorreu, levando em conta as leis do Canadá sobre tortura, a denegação de justiça do Irã e as obrigações internacionais do Canadá em virtude do artigo 14(1) da Convenção Contra a Tortura. Por conta dessas normas, a imunidade concedida pelo SIA, no caso Kazemi, viola princípios fundamentais de justiça. Além disso, deles decorre a obrigação do Canadá prover um remédio para a reparação civil daqueles que forem vítimas de tortura em um Estado estrangeiro e que a ausência de tal remédio é uma violação a princípios fundamentais de justiça, envolvendo, portanto, o artigo 7 da Canadian Charter.

O Advogado Geral do Canadá alegou que a abordagem dos apelantes adotou uma abordagem equivocada do artigo $7 \mathrm{da}$ Charter, falhando em identificar um princípio específico de justiça fundamental que tenha sido violado pelo Estado do Canadá no caso e buscando obter uma nova obrigação substancial do Canadá não prevista na Convenção Contra a Tortura, a saber, prover um mecanismo para reparação civil para vítimas de tortura no Canadá. Na visão do Advogado Geral, um princípio de justiça fundamental envolve significativo consenso na sociedade de que ele é fundamental para o modo pelo qual o sistema de justiça deve funcionar e deve ser identificado com suficiente precisão de modo a prover um padrão operacional pelo qual violações à vida, à liberdade ou à propriedade da pessoa possam ser mensuradas.

79 CANADA. Supreme Court of Canada. Estate of the Late Zabra (Ziba) Kazemi, et al. v. Islamic Republic of Iran. Available at: <http://www.scc-csc.gc.ca/case-dossier/info/sum-som-eng. aspx?cas $=35034>$. Last access on: 29 mai 2014.
No seu voto, o relator afirma não haver consenso de que o artigo 14 da Convenção Contra a Tortura deva ser interpretado da forma sugerida pelos apelantes, ao contrário, a interpretação do artigo 14 por diversos Estados e por tribunais internacionais e domésticos é no sentido de que a reparação prevista refere-se à tortura cometida dentro da jurisdição territorial do Estado-foro. Tem sido a posição adotada pelo Canadá e pelos Estados Unidos da América, acrescentou o relator, que o artigo 14 não exige que os Estados-partes na Convenção Contra a Tortura ofereçam mecanismos de reparação civil para atos de tortura comedidos em países estrangeiros ${ }^{80}$, argumento desenvolvido exaustivamente na decisão, com referências à jurisdição de diversas cortes e exame da redação do dispositivo e de suas possíveis interpretações, cuja análise mais detalhada é necessária e será objeto de próximo estudo.

Assim, a questão da violação ou não de preceitos fundamentais de justiça, bem como a interpretação das obrigações canadenses perante a comunidade internacional, decorrentes da Convenção Contra a Tortura se mostram os pontos-chave para a compreensão da posição canadense no caso, a qual sintetiza o posicionamento da maioria dos países quanto à matéria e expõe o problema crucial colocado no início deste artigo, qual seja, o conflito entre perspectivas substanciais e procedimentais do Direito Internacional Público. Chega-se à conclusão de que, em que pese o reconhecimento da relevância dos direitos violados, a sua proteção demanda uma engenharia processual, inexistente, no momento, que permita aos Estados ou à comunidade internacional oferecer às vítimas de tortura a possibilidade de uma reparação civil, de forma que, enquanto aquela não existir, a responsabilização civil não se mostra cabível.

No fechamento do voto do relator, sua manifestação foi pelo não conhecimento da apelação. Quanto às questões constitucionais, às perguntas se o artigo 3(1) do State Immunity Act é inconsistente com o artigo 2(e) do Canadian Bill of Rights e se ele infringe o artigo 7 da Canadian Charter of Rights and Freedoms, as respostas também foram negativas. ${ }^{81}$

80 CANADA. Supreme Court of Canada. Estate of the Late Zahra (Ziba) Kazemi, et al. v. Islamic Republic of Iran. Available at: $<$ http://www.scc-csc.gc.ca/case-dossier/info/sum-som-eng. aspx?cas $=35034>$. Last access on: 29 mai 2014.

81 CANADA. Supreme Court of Canada. Estate of the Late Zabra (Ziba) Kazemi, et al. v. Islamic Republic of Iran. Available at: <http://www.scc-csc.gc.ca/case-dossier/info/sum-som-eng. aspx?cas $=35034>$. Last access on: 29 mai 2014. 


\section{CONCLUSÃO}

Os Direitos Humanos são atualmente considerados, pela sociedade internacional, normas de jus cogens, cuja coercitividade se impõe independentemente da aceitação expressa dos Estados. O reconhecimento desta indispensabilidade de sua observância deu azo, por outro lado à elaboração de inúmeros tratados sobre a matéria, de forma que, se um Estado não a reconhecer com base no imperativo moral, deverá reconhecê-la no imperativo normativo positivado. A proibição da prática da tortura, por exemplo, regulada pela Convenção Contra a Tortura e Outros Tratamentos ou Penas Cruéis, Desumanos ou Degradantes (1984), como corolário direto da Declaração Universal dos Direitos do Homem, se imporia, nestes termos, no cenário do Direito Internacional como jus cogens, de forma que oponível a qualquer Estado, ainda que não tenha este concordado com os termos daquela Convenção de 1984.

Por outro lado, a doutrina da imunidade de jurisdição dos estados soberanos, baseada na construção do direito internacional a partir da vontade dos Estados, na soberania absoluta dos Estados independentes e no brocado latino par in parem non habet judicium, garante que nenhum Estado será submetido contra sua vontade à jurisdição de outro Estado, de forma que a prática de um ato antijurídico contra particulares, quando não cabível o instituto do endosso, ou a previsão de Corte Internacional com competência para tanto, não poderá gerar responsabilidade àquele sem que haja aceitação expressa quanto a sua subordinação à jurisdição estrangeira, ou que prevista exceção a esta garantia por meio de normas internas de fixação de competência e de jurisdição de cada Estado soberano, com vista1s a se garantir a manutenção da harmonia das relações internacionais.

Desta forma, são institutos de observância obrigatória no plano internacional no que diz respeito à atuação de cada Estado no exercício de sua soberania tanto a não transgressão de normas de jus cogens como a não interferência estrangeira na condução deste exercício. Esta dicotomia coloca para o Direito Internacional o problema da harmonização destes dois institutos, vez que o desrespeito a normas jus cogens, apesar de encontrar no ordenamento jurídico internacional imperativos para sua reparação e consequente responsabilização do Estado transgressor, encontra também naquele, bem como no ordenamento jurídico interno de alguns países, obstáculos a esta responsabilização, sendo o expoente máximo, objetivada na doutrina da imunidade de jurisdição.

Nota-se, nesse ínterim, uma convergência dos pensadores do Direito Internacional para a superação desta dicotomia, no sentido de se proceder a uma mudança no paradigma da soberania absoluta e da consequente imunidade de jurisdição dos Estados soberanos, baseada na teoria da anterioridade do Direito Internacional à própria noção de Estado e na soberania como conceito de Direito Internacional. Até mesmo Bodin "fez distinção entre leis e leis, afirmando que os soberanos estariam acima de leis particulares do país que ele governa, mas, como membro de uma comunidade humana, estaria sujeito à lei divina e natural e às leis das nações, pois, mesmo que se definisse a soberania como isenta de todas as leis, não haveria soberano que teria plenitude dos direitos em razão de que a lei divina e a lei natural abrangeria a todos, inclusive o soberano". ${ }^{82}$ No mesmo sentido, Francisco Rezek leciona ser a soberania atributo essencial do Estado que o faz titular de competências que, "porque precisamente existe uma ordem jurídica internacional, não são ilimitadas, mas nenhuma outra entidade as possui superiores". ${ }^{83}$

Este espírito é claramente observável nas condenações de responsáveis por crimes de tortura e genocídio, ou ainda na existência de projetos de lei nos Parlamento mundo à fora, a exemplo do canadense, que objetiva a emenda às Leis sobre imunidade de jurisdição de Estados soberanos, como o SIA ${ }^{84}$, para incluir a tortura e outras práticas no rol das exceções daquele Ato.

A indispensabilidade, porém, da proteção conferida pela garantia da imunidade de jurisdição à soberania, seja do Estado violador de normas jus cogens, seja daquele que pode dispor livremente sobre a delimitação de competência da sua Jurisdição, impede que aquele instituto seja superado, havendo consenso na jurisprudência internacional da imprescindibilidade de ato emanado do Legislativo de cada país para fins de fixação de exceções. Assim, o posicionamento da Corte canadense, no sentindo de proteger a imunidade do Estado iraniano, reflete este posicionamento ecoado na jurisprudência internacional, de que a questão do limite à imunidade de jurisdição de estados soberanos passa, muito mais pela questão política do posicionamento de cada Estado frente à possibilidade de se ver limitado nos mesmos termos, que propriamente pelo reconhecimento da gravidade das violações perpetradas.

82 MENEZES, Wagner. Tribunais internacionais: jurisdição e competência. São Paulo: Saraiva, 2013. p. 51.

83 REZEK, Francisco. Direito internacional público: curso elementar. 15. ed. São Paulo: Saraiva, 2014. p. 265.

84 CANADA. BILL C-10: an act to enact the justice for victims of terrorism act and to amend the state immunity act, the criminal code, the controlled drugs and substance act, the corrections and conditional release act, the youth criminal justice act, the immigration and refugee protection act and others acts. Available at: <http:// www.parl.gc.ca/About/Parliament/LegislativeSummaries/bills_ ls.asp?ls $=\mathrm{c} 10-02 \& \operatorname{Parl}=41 \&$ Ses $=1>$. Last access on: 25 mai 2014. 


\section{Referências}

ACCIOLY, Hildebrando; SILVA, G. E. Nascimento e; CASELLA, Paulo Borba. Manual de direito internacional público. 20. ed. São Paulo: Saraiva, 2012.

ALEXY, Conceito e validade do direito. 2. ed. Tradução Gercélia Batista de Oliveira Mendes. São Paulo: WMF Martins Fontes, 2011.

BODIN, Jean. Les six livres de la republique: livro i, capitulo viii, 1576. Disponível em: <http://gallica.bnf.fr/ ark:/12148/bpt6k6546272j.r $=$ monarchie + de + juillet. langPT>. Acesso em: 18 maio 2014.

BRASIL. Decreto n. 40, de 15 de fevereiro de 1991. Promulga a Convenção Contra a Tortura e Outros Tratamentos ou Penas Crueis, Desumanos ou Degradantes. Disponível em: <http://www.planalto.gov.br/ccivil_03/decreto/1990-1994/ D0040.htm>. Acesso em: 22 maio 2014.

BRASIL. Decreto n. 4.388, de 25 de setembro de 2002. Promulga o Estatuto de Roma do Tribunal Penal Internacional. Disponível em: <http://www.planalto. gov.br/ccivil_03/decreto/2002/D4388.htm> Acesso em: 22 maio 2014

CANADA. BILL C-10: an act to enact the justice for victims of terrorism act and to amend the state immunity act, the criminal code, the controlled drugs and substance act, the corrections and conditional release act, the youth criminal justice act, the immigration and refugee protection act and others acts. Available at: <http://www.parl.gc.ca/About/ Parliament/LegislativeSummaries/bills_ls.asp?ls=c1002\&Parl $=41 \&$ Ses $=1>$. Last access on: 25 mai 2014.

CANADA. Canadian Bill of Rights: S.C. 1960, c. 44. Available at: <http://laws-lois.justice.gc.ca/eng/ acts/c-12.3/page-1.html>. Last access on: 18 mai 2014.

CANADA. Constitution Act, 1867: an act for the union of Canada, Nova Scotia, and New Brunswick, and the government thereof; and for purposes connected therewith. Available at: <http://laws-lois.justice.gc.ca/eng/Const/ page-5.html\#docCont>. Last access on: 12 jun. 2014.

CANADA. Constitution Act, 1982 (80) Part I: Canadian charter of rights and freedoms. Available at: $<$ http://laws-lois.justice.gc.ca/eng/Const/page-15. html? texthighlight $=$ canadian charter of rights and freedoms\#inc>. Last access on: 18 mai 2014
CANADA. Quebec court of appeal. Islamic Republic of Iran C. Hashemi, 2012 QCCA 1449: case n. 500-09021440-110. Judges Yves-Marie Morissette, Richard Wagner, Clément Gascon. 15 ago 2012. Available at: $<$ http://www.jugements.qc.ca/php/decision.php?liste $=76814341 \& \mathrm{doc}=2 \mathrm{~B} 1951 \mathrm{E} 730 \mathrm{AB} 4 \mathrm{~F} 1 \mathrm{BFC} 7 \mathrm{DE} 8781 \mathrm{E} 4$ 0C2D3A534A6207CECDBF438486FE01E90FD30\& page $=1>$. Last access on: 29 mai 2014 .

CANADA. Quebec Superior Court of Justice. Kazemi (Estate of) C. Islamic Republic of Iran, 2011 QCCS 196 (Canlii): Case n ${ }^{\circ}$ 500-17-031760-062. Judge Robert Mongeon. 26 jan 2011. Available at: < http://canlii.ca/ t/2fh0s>. Last access on: 29 maio 2014.

CANADA. Quebec Civil Code. Available at: $<$ http://www2.publicationsduquebec.gouv.qc.ca/ dynamicSearch/telecharge.php? type $=2 \&$ file $=/$ CCQ_1991/CCQ1991_A.htm>. Last access on: 12 jun. 2014.

CANADA. Quebec Code of Civil Procedure. Available at: $<$ http://www2.publicationsduquebec.gouv.qc.ca/ dynamicSearch/telecharge.php?type $=2 \&$ file $=/ C \_25 /$ C25_A.HTM>. Last access on: 12 jun. 2014.

CANADA. Supreme Court Act: An Act respecting the Supreme Court of Canada. Available at: <http://lawslois.justice.gc.ca/eng/acts/S-26/FullText.html>. Last access on: 12 jun. 2014.

CANADA. Supreme Court of Canada. Estate of the Late Zahra (Ziba) Kazemi, et al. v. Islamic Republic of Iran. Available at: <http://www.scc-csc.gc.ca/case-dossier/ info/sum-som-eng.aspx?cas $=35034>$. Last access on: 29 mai 2014.

CANADA. State Immunity Act: An Act to provide for state immunity in Canadian courts. Available at: $<$ http://laws-lois.justice.gc.ca/PDF/S-18.pdf > $\quad$ Last access on: 27 jun. 2014.

CASTRO, Thales. Teoria das relaçôes internacionais. Brasília: FUNAG, 2012. Available at: < http://funag. gov.br/loja/download/931-Teoria_das__ Relacoes_ Internacionais.pdf $>$. Last access on: 30 jun. 2014

CHEVALIER, Jean-Jacques. As grandes obras politicas de Maquiavel a nossos dias. 8. ed. Rio de Janeiro: AGIR, 1999. Disponível em: <http://mpassosbr.files. wordpress. com/2013/03/as-grandes-obras-polc3adticas-de- 
maquiavel-a-nossos-dias-jean-jacques-chevallier-riode-janeiro_-agir-1999.pdf>. Acesso em: 18 maio 2014.

FINKELSTEIN, Cláudio. Hierarquia das normas no direito internacional: jus cogens e metaconstitucionalismo. São Paulo: Saraiva, 2013.

LIMA, Renata Matovani de; ALVES, Renata de Sena. A efetividade do ativismo jurídico transnacional no Sistema Interamericano de Direitos Humanos: uma análise a partir de casos contra o Brasil. Revista de Direito Internacional, Brasília, v. 10, n. 2, p. 239-241, 2013.

MENEZES, Wagner. Tribunais internacionais: jurisdição e competência. São Paulo: Saraiva, 2013.

NASSER, Salem Hikmat. Jus Cogens: ainda esse desconhecido. RevistaDireitoGV,v.1,n.2,p.161-178,jun./ dez. 2005. Disponível em: <http://bibliotecadigital.fgv. br/dspace/bitstream/handle/10438/9658/Salem\%20 Hikmat $\% 20$ Nasser.pdf?sequence $=1>$. Acesso em: 18 maio 2014.

ONU. Convenção das Nações Unidas contra a tortura $e$ outros tratamentos ou penas cruéis, desumanos ou degradantes: Resolução 39/46 da Assembleia Geral das Nações Unidas, de 10 de dezembro de 1984. Disponível em: $<$ http://bvsms.saude.gov.br/bvs/publicacoes/ conv_ contra_tortura.pdf $>$. Acesso em: 22 maio 2014

ONU. Estatuto de Roma: U.N. Doc. A/CONF.183/9*. Disponível em: <http://legal.un.org/icc/statute/ romefra.htm>. Acesso em 22 maio 2014

PIOVESAN, Flávia. A Proteção Internacional dos Direitos Humanos das Mulheres. Revista EMERJ, Rio de Janeiro, v. 15, n. 57, Ed. Especial. p. 70-89, jan./mar. 2012. Disponível em: <http://www.emerj.tjri.jus.br/ revistaemerj_online/edicoes/revista57/revista57_70. pdf>. Acesso em: 22 maio 2014

REZEK, Francisco. Direito internacional público: curso elementar. 15. ed. São Paulo: Saraiva, 2014.
SOARES, Guido E. Silva; MENDES, Gilmar Ferreira; GARCIA, Márcio Pereira Pinto. Imunidade de jurisdição: evolução e tendências. In: IMUNIDADE soberana: o estado estrangeiro diante do juiz nacional. Brasília: CEJ, 2001. (Série Cadernos do CEJ, v. 19). Disponível em: <http://daleth.cjf.jus.br/revista/ seriecadernos/ vol19.pdf $>$. Acesso em: 23 maio 2014

SOUSA, Mônica Tereza C. Imunidade de Jurisdição de Estado Estrangeiro: aspectos doutrinários e a jurisprudência brasileira. Revista Sequência, Florianópolis, v. 21, n. 40, 2000. Disponível em: <https://periodicos. ufsc.br/index.php/sequencia/article/view/15442>. Acesso em: 23 maio 2014.

TAIAR. Rogério. Direito internacional dos direitos bumanos: uma discussão sobre a relativização da soberania face à efetivação da proteção internacional de direitos humanos. 2009. 321f. Tese (Doutorado em Direitos Humanos)-Faculdade de Direito, Universidade de São Paulo, São Paulo, 2009. Disponível em: <http://www. teses.usp.br/teses/disponiveis/2/2140/tde-24112009133818/pt-br.php>. Acesso em: 18 maio 2014.

TOLEDO JÚNIOR, Milton Nunes. Direito Internacional Imperativo: jus cogens. 2006. 120f. Dissertação (Mestrado em Direito Internacional Econômico)-Universidade Católica de Brasília, Brasília, 2006. Disponível em: $<$ http://www.bdtd.ucb.br/tede/tde_busca/arquivo. php?codArquivo=285>. Acesso em: 22 maio 2014.

UNITED STATES OF AMERICA. 28 US Code $\int 1605 A$ : Terrorism exception to the jurisdictional immunity of a foreign state. Disponível em: <http:// www.law.cornell.edu/uscode/text/28/1605A $>$. Acesso em: 27 jun. 2014.

VERDROSS, Alfred. O Fundamento do Direito Internacional. Revista de Direito Internacional, v. 10, n. 2, p. 1-33, 2013. Disponível em: <http://www. publicacoesacademicas.uniceub.br/index.php/rdi/ article/view/2685>. Acesso em: 23 abr. 2014. 
Para publicar na Revista de Direito Internacional, acesse o endereço eletrônico www.rdi.uniceub.br ou www.brazilianjournal.org.

Observe as normas de publicação, para facilitar e agilizar o trabalho de edição. 